University of Nebraska - Lincoln

DigitalCommons@University of Nebraska - Lincoln

\title{
A model-based exploratory study of sulfur dioxide dispersions from concentrated animal feeding operations in the Southeastern United States
}

Jesse Winchester

Rezaul Mahmood

William Rodgers

Philip J. Silva

Nanh Lovanh

See next page for additional authors

Follow this and additional works at: https://digitalcommons.unl.edu/hprccpubs

Part of the Atmospheric Sciences Commons, Climate Commons, Environmental Indicators and Impact Assessment Commons, Environmental Monitoring Commons, Fresh Water Studies Commons, Hydrology Commons, Meteorology Commons, Natural Resources Management and Policy Commons, Sustainability Commons, and the Water Resource Management Commons

This Article is brought to you for free and open access by the High Plains Regional Climate Center at DigitalCommons@University of Nebraska - Lincoln. It has been accepted for inclusion in HPRCC Personnel Publications by an authorized administrator of DigitalCommons@University of Nebraska - Lincoln. 
Authors

Jesse Winchester, Rezaul Mahmood, William Rodgers, Philip J. Silva, Nanh Lovanh, Joshua D. Durkee, and John Loughrin 


\title{
A model-based exploratory study of sulfur dioxide dispersions from concentrated animal feeding operations in the Southeastern United States
}

\author{
Jesse Winchester ${ }^{\mathrm{a}, \mathrm{b}}$, Rezaul Mahmood ${ }^{\mathrm{c}}$, William Rodgers (D) ${ }^{\mathrm{a}, \mathrm{b}}$, Philip J. Silva ${ }^{\mathrm{d}}$, \\ Nanh Lovanh ${ }^{d}$, Joshua Durkee ${ }^{a}$ and John Loughrin ${ }^{d}$
}

${ }^{a}$ Department of Earth, Environmental, and Atmospheric Sciences, Bowling Green, KY, USA; ${ }^{\text {b}}$ Kentucky Climate Center, Western Kentucky University, Bowling Green, KY, USA; 'High Plains Regional Climate Center, School of Natural Resources, University of Nebraska-Lincoln, Bowling Green, KY, USA; dUSDA-ARS, Bowling Green, Kentucky

\begin{abstract}
In the Southeastern U. S. there are Concentrated Animal Feeding Operations (CAFOs) that emit a variety of gases, including $\mathrm{SO}_{2}$. Sulfur is emitted as reduced sulfur compounds and can react in the atmosphere to produce $\mathrm{SO}_{2}$. It is expected that the concentration and spread of $\mathrm{SO}_{2}$ emissions from these sources would differ between wet and dry periods. In this research, $\mathrm{SO}_{2}$ emissions from locations representing CAFOs and its dispersion over the southeastern U.S. were simulated through sensitivity experiments using the Weather Research and Forecasting-Chemistry (WRF- Chem) model. Simulations were performed for dry periods and precipitation events that occurred over western Kentucky between July 7 and 13 July 2012.

The study found that spatial coverage of $\mathrm{SO}_{2}$ dispersion originating from these locations was reduced during precipitation events and expanded during dry periods. The average concentration of $\mathrm{SO}_{2}$ over the study area was also higher during the breaks between precipitation events than during precipitation. The highest concentrations of $\mathrm{SO}_{2}$ exceeding 1,000 pptv remained within close range of the emission locations for the majority of the simulations, except for when local surface wind speeds were high. Most emissions from the locations remained limited to the surface and lower levels of the atmosphere $(850 \mathrm{mb})$.
\end{abstract}

\section{ARTICLE HISTORY}

Received 5 June 2019

Accepted 10 January 2021

\section{KEYWORDS}

Sulfur dioxide; livestock; dispersion; modeling; WRFChem; Southeastern United States

\section{Introduction}

Air pollution can be hazardous to human health, flora and fauna (Borlée et al., 2017; Khaniabadia et al., 2017; Pope \& Dockery, 2006; Pope et al., 1991; Sigurdarson \& Kline, 2006). Pope and Dockery (2006) noted that air pollution can adversely impacts Cardiovascular health. Borlée et al. (2017) suggested that air pollution from livestock farms negatively impacts non- farming population and their lung function. Mnatzaganian et al. (2015) found that in Maui, Hawaii, there was a significantly higher occurrences of respiratory distress in smoke-affected areas, linked to sugar cane farming. 
Khan and Siddiqui (2014) also noted that respiratory system and lung functions can be impacted by higher level of sulfur dioxide $\left(\mathrm{SO}_{2}\right)$ in the air.

Pollutants such as sulfur dioxide $\left(\mathrm{SO}_{2}\right)$ are emitted from a wide variety of natural and anthropogenic sources. Natural sources include vegetation and water bodies, and anthropogenic sources include agricultural operations, industry, transportation networks, and cities (Battye et al., 2003; Cicerone \& Oremland, 1988; Kleinman et al., 2002; Mosier et al., 1998). In agriculture, Concentrated Animal Feeding Operations (CAFOs) are a potentially important source of $\mathrm{SO}_{2}$ emissions (Bunton et al., 2007). Note that the agriculture is not a major direct emissions source of $\mathrm{SO}_{2}$, however, it does release other reduced sulfur compounds that can photochemically oxidize to $\mathrm{SO}_{2}$. These may become increasingly important contributors to particulate formation as direct $\mathrm{SO}_{2}$ emissions are reduced (Perraud et al., 2015). Since these emissions can be harmful to human health and the environment in general, it is crucial that we investigate $\mathrm{SO}_{2}$ emissions and their dispersion under different atmospheric conditions.

This paper focuses on the spatial and temporal patterns of transport and dispersion of simulated emissions across a portion of the southeastern U.S. Specifically, these point sources represent CAFOs in western Kentucky near Bandana, Cunningham, and Boxville (Figure 1). We have selected $\mathrm{SO}_{2}$ because it is part of a larger study. These emissions were modeled in the context of periodic convective precipitation and dry periods through the week of July 7-13, 2012 over the study area. The Weather Research and ForecastingChemistry (WRF-Chem) model was used to simulate emission dispersion. This is one of the first applications of WRF-Chem for agricultural/livestock emissions and dispersion. These simulations also provided an opportunity to assess WRF model-sensitivity and performance for this type of applications in the future. The length of the experiment is

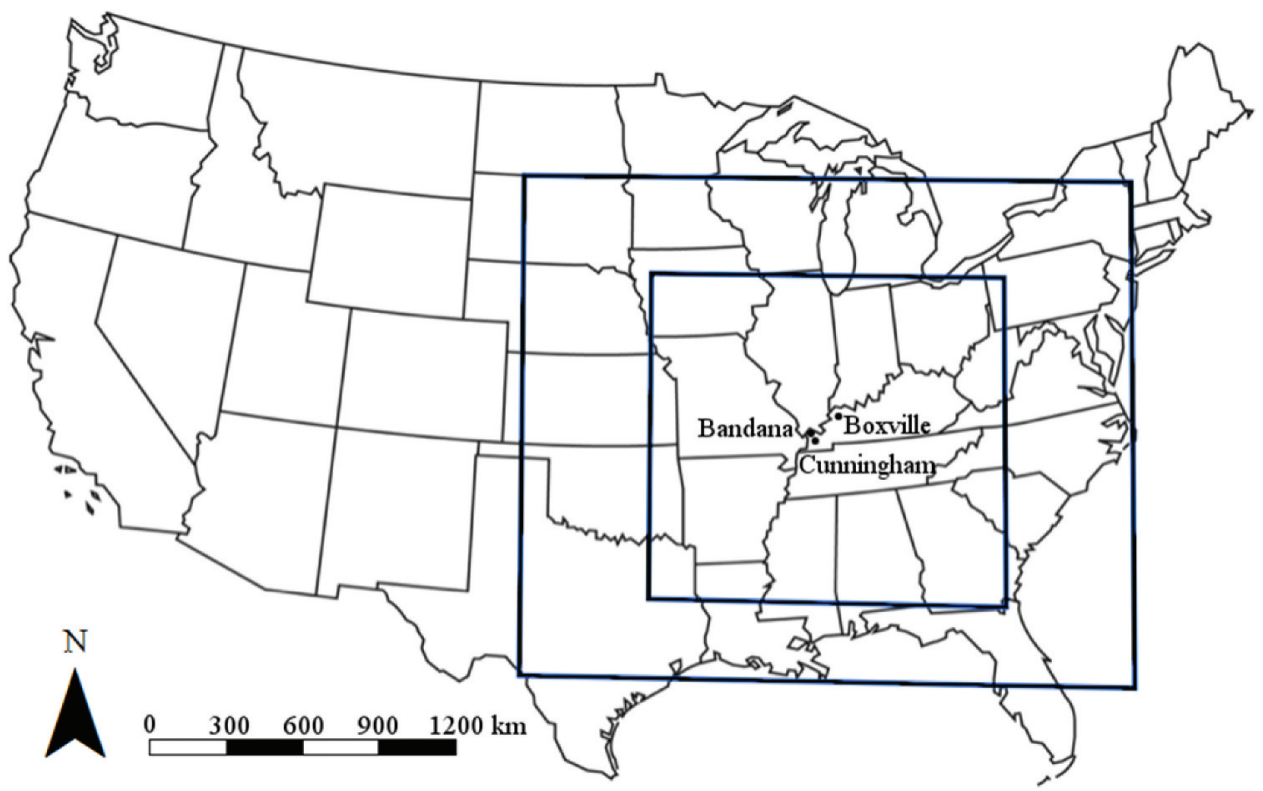

Figure 1. Inner and outer domains for the sensitivity simulations. Emission sources are labeled points within the inner domain. 
generally acceptable in the air quality research involving models or observations (e. g., Loughner et al., 2011; Wang et al., 2011).

Precipitation can enhance the rate at which $\mathrm{SO}_{2}$ is oxidized to produce sulfuric acid $\left(\mathrm{H}_{2} \mathrm{SO}_{4}\right)$, a component of acid rain at high $\mathrm{SO}_{2}$ concentrations (Menz \& Seip, 2004). Hence, this study suggests that the presence of precipitation over the emission locations would result in changes to atmospheric concentration of $\mathrm{SO}_{2}$ in their vicinity and the geographic dispersion of emissions was expected to change during precipitation in comparison to drier conditions.

Previous air pollution studies include global-scale simulations of greenhouse gas concentrations, regional-scale simulations of surface emissions and transport (Jiang et al., 2010), and smaller-scale urban emission studies focused on temporal persistence and effects on the surrounding area (Jiang \& Zhao, 2008; Karl et al., 2009; Kleinman et al., 2002; Tie et al., 2007). Compared to these studies, a limited number have focused on anthropogenic emissions from rural and agricultural environments and, in particular, from CAFOs (Loughrin et al., 2011; Quintanar et al., 2013). These research suggest that the impacts of CAFOs on air quality warrant attention due to the nearby human settlements and inhabitants. and provided further motivation for the current study.

The results of the present research provide insight into the short-term emissions from CAFOs and their dispersion. This may also offer a framework within which future CAFO emission and dispersion studies at a similar scale can be performed for other locations. In the following sections this paper provides a literature review, brief assessment of the research questions, and methodology of the research project, followed by the results and conclusions. Components of the methodology include descriptions of the extent of the study area, event selection process, data and variables, modeling steps, and analysis. This paper concludes with a summary of the overall findings as well as statements explaining the significance and justification of the selected research topic.

Although this study verified precipitation amounts simulated by the model with observed data, a limitation of this is that we did not have observed $\mathrm{SO}_{2}$ data for the study periods for such verification. However, we have compared simulated $\mathrm{SO}_{2}$ with other observed studies to ensure that the simulated values are satisfactory (e.g. Loughner et al., 2011).

\section{Background}

A facility to qualify as an Animal Feeding Operation (AFO), must have animals in a concentrated area for at least 45 days of a given year. Animals include hogs, cattle, chickens, hens, and pullets. There are over 400,000 of these operations across the U.S. [United States Department of Agriculture [USDA], 2013]. The classification of an AFO as a CAFO depends on the animal species and the number of animals in a facility (Environmental Protection Agency [EPA], 2014). Different types of CAFOs, in terms of animals, are distributed across the U.S. in various patterns. For example, pig operations are concentrated in the Midwest and eastern North Carolina, while chicken operations occur in clusters scattered throughout the Southeastern US (National Research Council, 2003).

There are several gases/pollutants emit from CAFOs. These include $\mathrm{CH}_{4}, \mathrm{CO}_{2}, \mathrm{~N}_{2} \mathrm{O}$, $\mathrm{NH}_{3}$, hydrogen sulfide $\left(\mathrm{H}_{2} \mathrm{~S}\right)$, and $\mathrm{SO}_{2}$ (Bunton et al., 2007). In addition to gaseous 
emissions, others such as volatile organic compounds (VOCs) and particulate matter can also be found (Ni et al., 2012; Winkel et al., 2015; Zhang et al., 2019). Particulate matter emitted from CAFOs can be composed of a complicated mix of inorganic, organic, and biological components.

Particulate matter that originates from CAFOs can cause respiratory problems, such as asthma, and can occur in human populations in the vicinity of these operations (Sigurdarson \& Kline, 2006). CAFO emissions can also produce secondary particulate matter (aerosol that forms from atmospheric chemical reactions). Ammonia is known to contribute to this end and it is suspected that sulfur and VOC compounds may as well. As noted above, CAFOs emit reduced sulfur compounds that include $\mathrm{H}_{2} \mathrm{~S}$ and organic analogues such as dimethylsulfide (DMS) and methanethiol, which can react in the atmosphere to produce $\mathrm{SO}_{2}$ and other sulfur species (Rumsey \& Aneja, 2009). Feilberg et al. (2017) correctly noted that $\mathrm{H}_{2} \mathrm{~S}$ from agricultural sources is generally not included in sulfur emission estimates although it is a major sulfur compound emitted from livestock production. They have also found that livestock farming, particularly pig production, is a major agricultural source of sulfur in Denmark. It is well-known that $\mathrm{H}_{2} \mathrm{~S}$ and $\mathrm{OH}$ reacts in the atmosphere and has an estimated lifespan of 2.5 days (Feilberg et al., 2017). On the other hand, the atmospheric lifespan of $\mathrm{SO}_{2}$ can be 4 to $48 \mathrm{~h}$ (Feilberg et al., 2017). This also suggests that conversion of $\mathrm{H}_{2} \mathrm{~S}$ to aerosol sulfate can occur over a short period of time (Feilberg et al., 2017). In addition, the chemical characteristics of $\mathrm{H}_{2} \mathrm{~S}$ is different from $\mathrm{SO}_{2}$ especially due to a much lower water uptake of $\mathrm{H}_{2} \mathrm{~S}$ (and can have implications in simulations of dispersions if we have considered $\mathrm{H}_{2} \mathrm{~S}$ ).

Global and large-scale air quality simulations are useful for obtaining the big picture of emission rates, atmospheric transport and persistence (e.g. Chen et al., 2019; Guenther et al., 2006; Niemeier et al., 2020). Emission sources in these studies are almost always areal in nature due to their large spatial scope. In addition, low spatial resolution does not allow emissions from point sources, such as individual urban plumes, to be resolved. Specific applications also include present-day assessments of emissions from varying land cover types. For example, isoprene emission factors from several vegetation species have been modeled across the globe using MEGAN (Guenther et al., 2006).

Air quality research with a regional and local focus provides smaller-scale details. Examples include studies over western and central Europe (Kim et al., 2011), the southeastern U.S. (Chuang et al., 2011), the northeastern U.S. (Ntelekos et al., 2009; Wilczak et al., 2006) and along the West Coast (Bernstein et al., 2012). The present study provides an example of both farm and regional-scale assessment $\mathrm{SO}_{2}$ emission and dispersion from several CAFOs in Western Kentucky. It is one of the few modeling studies that focuses on agricultural $\mathrm{SO}_{2}$ emissions. While $\mathrm{SO}_{2}$ is not the major sulfur component from agricultural sources, this basic optimization must be performed prior to taking more complicated steps of looking at reduced sulfur compounds and adding their chemistry to the models to produce sulfur products downwind. Future experiments in this area will add in the chemistry of reduced sulfur compounds. The two most important would be $\mathrm{H}_{2} \mathrm{~S}$ because of its high concentration in agricultural source emissions and DMS because of its potential importance in producing secondary aerosols. 


\section{Methodology}

\section{The WRF-Chem model and experimental set-up}

The Weather Research and Forecasting model with Chemistry (WRF-Chem) was developed by the National Center for Atmospheric Research [National Center for Atmospheric Research [NCAR] 2013] and has been used in a number of air quality related studies (Bernstein et al., 2012; Chapman et al., 2009; Jiang et al., 2010; Jiang \& Zhao, 2008; Lee et al., 2011; Lin et al., 2010; Loughner et al., 2011; Ntelekos et al., 2009; Saide et al., 2011, 2011; Wang et al., 2010; Wu et al., 2011; Yerramilli et al., 2009; Zhang et al., 2010). WRF-Chem version 3.4.1, released in August 2012, was used to perform the simulations for this research. The simulations used North American Regional Reanalysis A (NARR-A) data produced by the National Centers for Environmental Prediction (NCEP) and distributed via the National Operation Model Archive and Distribution System (NOMADS) (Mesinger et al., 2006). The data have a horizontal resolution of $32 \mathrm{~km}$ and were prepared at three-hour intervals $(00,03,06,09,12,15,18$, and 21 UTC). Variables such as geopotential height, specific humidity, cloud water, mixing ratios, and wind vectors were available for 29 pressure levels.

A number of variables were provided at specific heights above the surface, including temperature, specific humidity, and pressure at 2, 10, and $30 \mathrm{~m}$; potential temperature and horizontal wind vectors at 2 and $10 \mathrm{~m}$; and dew point temperature and relative humidity at $2 \mathrm{~m}$ above the surface. Over 30 variables were available for the near surface, including temperature, precipitation, radiation and energy fluxes, pressure, planetary boundary layer (PBL) height, vegetation cover, and albedo. Soil moisture and temperature were also included for four soil levels $(0-10 \mathrm{~cm}, 10-40 \mathrm{~cm}, 40-100 \mathrm{~cm}$, and $100-200 \mathrm{~cm}$ ). Each simulation was seven days long and a total of 56 observations periods were used for each event ( 8 observations per day $\mathrm{x} 7$ days) to model upper atmospheric, near surface, and subsurface conditions.

Physical parameterization schemes were selected first. There are options for the land surface model (which controls surface conditions such as energy fluxes), cumulus and convective parameterization, short-wave and long-wave radiation schemes, planetary boundary layer, and others. Parameterization schemes used are listed in Table 1. Time intervals and domain resolution were also specified in this phase.

The second phase involved the chemistry parameterization of the model. Similar to the physics options in the previous phase, various settings were available, including chemical species, photolysis, anthropogenic emissions, and biogenic emissions. To handle $\mathrm{SO}_{2}$ chemistry, we have used Second Generation Regional Acid Deposition Model

Table 1. Parameterization schemes used for the WRF-Chem simulations.

\begin{tabular}{lll}
\hline Parameter & \multicolumn{1}{c}{ Scheme } & \multicolumn{1}{c}{ Reference } \\
\hline Cloud microphysics & WRF Single-Moment 6-class & Hong \& Lim, 2006 \\
Longwave radiation & Rapid Radiative Transfer Model & Mlawer et al., 1997 \\
Shortwave radiation & RRTMG Shortwave & Mlawer et al., 1997 \\
Surface layer & MM5 Similarity & Grell et al., 1994 \\
Land surface & Noah Land Surface Model & Chen \& Dudhia, 2001 \\
Urban surface & None & \\
Planetary boundary layer & Yonsei University & Hong et al., 2006 \\
Cumulus parameterization & Kain-Fritsch & Kain \& Fritsch, 1993 \\
\hline
\end{tabular}


Mechanism (RADM2) parameterization scheme for gas and aqueous phase reactions (Gross \& Stockwell, 2003). The RADM2 includes the oxidation of $\mathrm{SO}_{2}$ by $\mathrm{OH}$ (Stockwell et al., 1990; Egan et al., 2014). Gaseous precursors, such as NO and OH, were included in the model using the Prep-Chem-Source 1.4 preprocessor (Freitas et al., 2011). In the model $\mathrm{SO}_{2}$ converts via aqueous phase chemistry with $\mathrm{OH}$. In the RADM2, $\mathrm{SO}_{2}$ and $\mathrm{NO}_{2}$ reacts with $\mathrm{OH}$ and are the major gas phase sources of $\mathrm{H}_{2} \mathrm{SO}_{4}$ and $\mathrm{HNO}_{3}$, respectively (Stockwell et al., 1990). Reaction of $\mathrm{SO}_{2}$ with $\mathrm{OH}$ can be shown as follows:

$$
\begin{aligned}
& \mathrm{SO}_{2}+\mathrm{OH}(+\mathrm{M}) \rightarrow \mathrm{HOSO}_{2}(+\mathrm{M}) \\
& \mathrm{HOSO}_{2}+\mathrm{O}_{2} \rightarrow \mathrm{SO}_{3}+\mathrm{HO}_{2} \\
& \mathrm{SO}_{3}+\mathrm{H}_{2} \mathrm{O} \rightarrow \mathrm{H}_{2} \mathrm{SO}_{4} \\
& \mathrm{HO}_{2}+\mathrm{NO} \rightarrow \mathrm{HO}+\mathrm{NO}_{2}
\end{aligned}
$$

Stockwell et al. (1990) noted that previous experimental work (Margitan, 1984; Meagher et al., 1984,; Gleason et al., 1987) verified $\mathrm{SO}_{2}-\mathrm{OH}$ chain mechanism. In addition, RADM2 is coupled with the aerosols module the Modal Aerosol Dynamics Model for Europe (MADE) (Ackermann et al., 1998; Binkowski \& Shankar, 1995) and the Secondary Organic Aerosol Model (SORGAM) (Schell et al., 2001). MADE/SORGAM predict aerosol distribution and dynamics and quantify nucleation, coagulation, condensation, and dry deposition.

The locations of the three CAFO sites selected in western Kentucky are within the inner domain and their emissions were specified. Four simulations were completed for each event, with the first simulation being the control run with no emissions change. The other three simulations included $\mathrm{SO}_{2}$ emissions increases at these three locations and they were $10 \%, 20 \%$, and $30 \%$. Increasing emissions from the three locations isolate emissions from surrounding, allowing for identifying their particular contribution to atmospheric concentration via comparisons with the control simulation. For seven- day model simulations, each simulation took up to four actual days to complete.

This research used two domains to cover the study area. A larger area (outer domain) provided context within which the main study area (inner domain) was located (Figure 1). The outer domain spanned much of the eastern half of the U.S and had a spatial resolution of $12 \mathrm{~km}$. This domain had a south-north extent ranging from $28^{\circ} \mathrm{N}$, just off the Gulf Coast, to $45^{\circ} \mathrm{N}$ across the Great Lakes. The west-to-east extent was from $-101^{\circ}$ $\mathrm{W}$ in the Great Plains to $-75^{\circ} \mathrm{W}$ along the East Coast.

The inner domain contained the southeastern U.S. with a specific focus on western Kentucky, and had a spatial resolution of $4 \mathrm{~km}$. The inner domain extended from $32^{\circ} \mathrm{N}$ to $42^{\circ} \mathrm{N}$ and $-96^{\circ}$ to $-81^{\circ} \mathrm{W}$, spanning portions of 21 states (see Figure 1). The CAFOs in the study area primarily house pigs and chickens. Pig operations are more scattered, while chicken operations occur in concentrated areas. Of these operations, three CAFO sites were selected for the emission simulations and they were located near Cunningham, $\mathrm{KY}\left(36.91^{\circ}\right.$ $\mathrm{N}$ and $\left.88.85^{\circ} \mathrm{W}\right)$, near Bandana, $\mathrm{KY}\left(37.16^{\circ} \mathrm{N}\right.$ and $\left.88.96^{\circ} \mathrm{W}\right)$, and near Boxville, $\mathrm{KY}\left(37.65^{\circ}\right.$ $\mathrm{N}$ and $87.78^{\circ} \mathrm{W}$ ) (Figure 2). The sites represent minimal or no influence from other anthropogenic emission sources such as cities, industries and interstates.

In addition, the locations were determined by overlaying data points from the National Emissions Inventory of 2005 (NEI05) on pig CAFO maps produced by the National Research Council (2003). Several matches of CAFO locations and NEI05 data points in western Kentucky were identified. The coordinates of the corresponding NEI05 data points were obtained and used to verify the locations with satellite imagery. Again, 


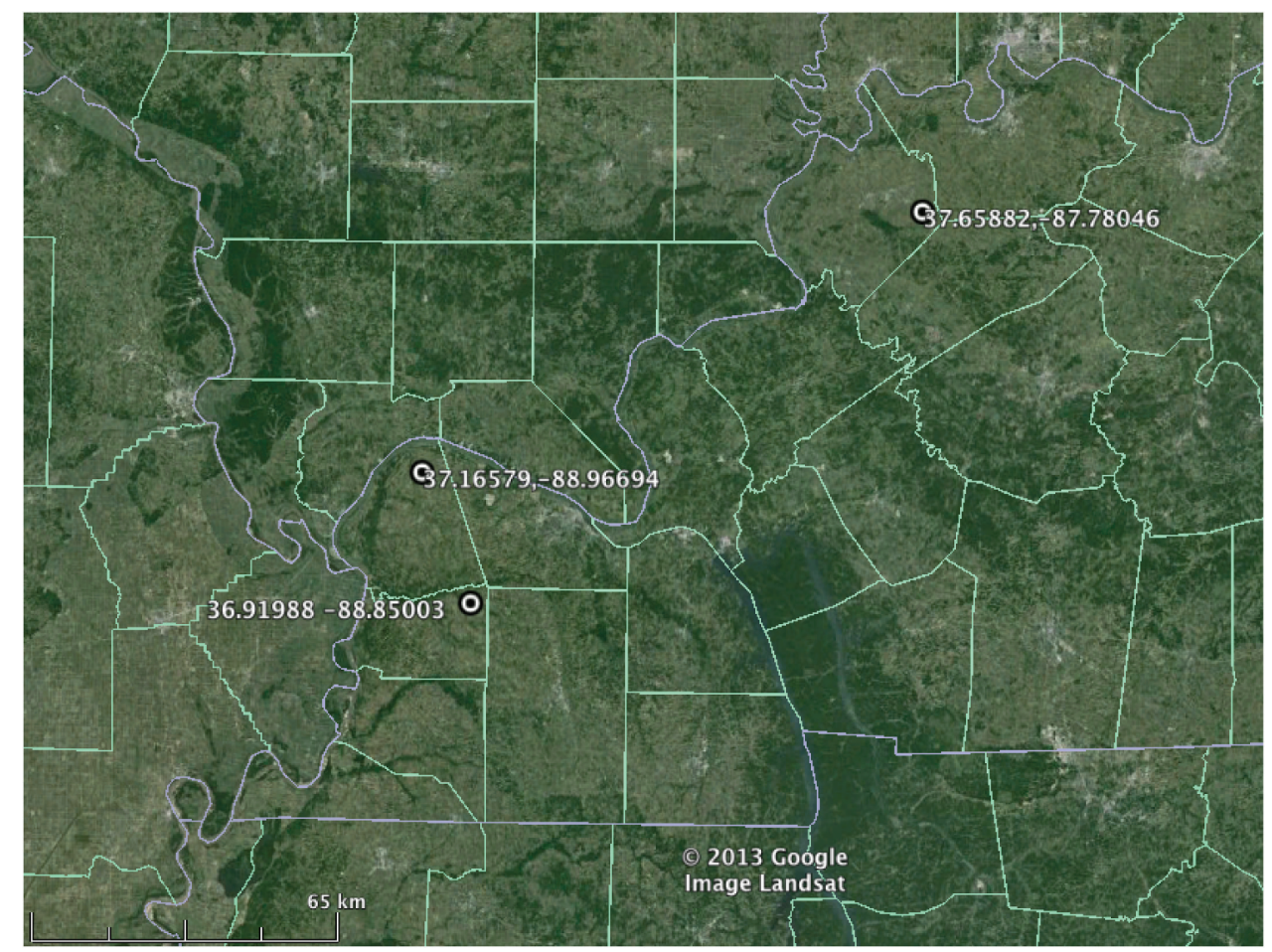

Figure 2. The locations where emissions near CAFOs in Western Kentucky were changed during the sensitivity simulations. Source: Base Map from Google Earth (2014).

this was to ensure that locations were not near any other anthropogenic sources of emissions.

\section{Event selection}

Emission simulations were performed for the period of 7-13 July 2012 which included rainy and dry periods. The process of identifying a suitable event began with the examination of observed daily precipitation maps produced by the Advanced Hydrologic Prediction Service (AHPS), a branch of the National Weather Service (NWS) (Figure 3). Over 3,000 daily maps from the AHPS precipitation image archive (2 January 2005, to 8 October 2013) were analyzed to estimate area-averaged precipitation for the inner domain.

After calculating daily area average precipitation for the inner domain for the entire map archive, they were grouped into seven-day averages. Peaks in period average precipitation were visually verified with the appropriate AHPS daily precipitation maps to check the location and characteristics of rainfall patterns. The estimated precipitation amounts during this event for the three locations selected in western Kentucky are shown in Table 2.

The following results section includes a brief discussion on synoptic condition, control simulation, and results from sensitivity experiments. 


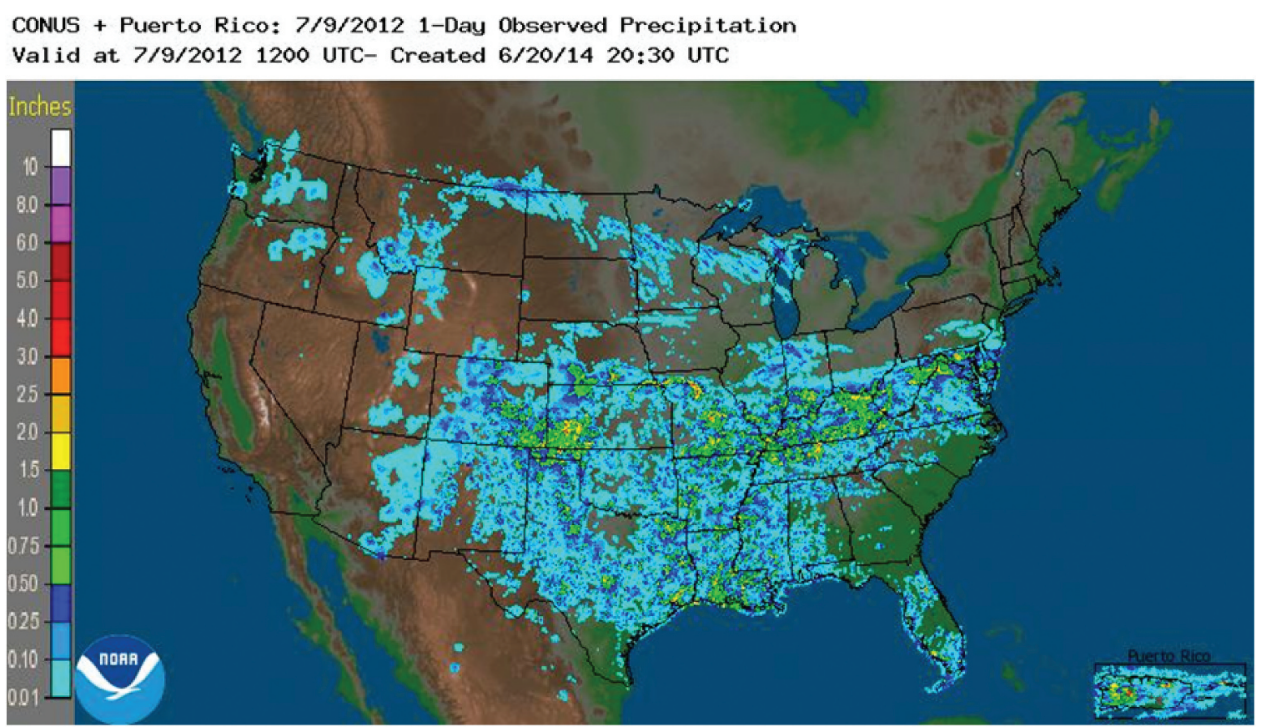

Figure 3. Daily precipitation map for the southeastern U.S. during the 24 hours ending at 1200 UTC on 9 July 2012. Source: AHPS (2012).

Table 2. Estimated precipitation amounts for the three selected locations during the July 7-13, 2012 event as derived from the AHPS daily precipitation maps (AHPS, 2012).

\begin{tabular}{ll}
\hline Location & Precipitation $(\mathrm{mm})$ \\
\hline Rainfall $1.8 \mathrm{mi} \mathrm{NW}$ of Bandana, $\mathrm{KY}$ & $51.56 \mathrm{~mm}$ \\
Rainfall $2.4 \mathrm{mi}$ NE of Cunningham, KY & $57.40 \mathrm{~mm}$ \\
Rainfall $3.3 \mathrm{mi}$ NE of Boxville, KY & $14.22 \mathrm{~mm}$ \\
\hline
\end{tabular}

\section{Results and discussions}

\section{Observed synoptic conditions}

The gradual passage of a quasi-stationary front played an important role in the precipitation of July 7-13, 2012. On July 7, a cold front over the Great Lakes became stationary and started to drift slowly southward by July 8 before reaching western Kentucky on July 9 and Tennessee by July 10. The front continued over Mississippi and Alabama through July 11-12. A low-pressure center developed over the study area on July 13. Daily radar- estimated precipitation maps showed that western Kentucky received at least $1 \mathrm{~mm}$ of rainfall every day during this 7-day period. Most of the precipitation was observed on July 9, with some areas of western Kentucky exceeding $25 \mathrm{~mm}$ of rainfall coinciding with the passage of the stationary front over the study area. Doppler radar imagery also documented the passage of the stationary front. The band of rainfall associated with the front was directly over western Kentucky at 0000 UTC on July 9, or 7:00 P.M. LST. The precipitation band contained more active convective cells at 0000 
UTC (7:00 P.M. CDT), likely due to daytime heating contributing to a more unstable atmosphere.

\section{Results from the control (CTRL) simulation}

The simulation of accumulated precipitation in the inner domain had a diurnal pattern, with a gradual increase from 0300 UTC to 1800 UTC each day, and a rapid increase between 1800 UTC and 0300 UTC of the next day, which coincided with the warmest part of each day. By the end of the simulation period, the inner domain had an area average accumulated precipitation of $39 \mathrm{~mm}$ (Figure 4(a)). The diurnal pattern was not as pronounced for accumulated precipitation in and around western Kentucky, with the first main rainfall event not occurring until late on July 8 (Figure 4(b)). Several smaller accumulations of 1-2 mm occurred from July 9 to July 11, and larger accumulation events exceeding $8 \mathrm{~mm}$ occurred on July 12 and 13 . These resulted in a total area average accumulation of $33 \mathrm{~mm}$ over western Kentucky (Figure 4(b)).

Maps of accumulated precipitation for the inner domain showed that most of the precipitation in Arkansas occurred on or before July 11. This area of the highest accumulations expanded eastward into Mississippi and Tennessee on July 12 and into Alabama on July 13. Overall, the simulation produced a larger amount of precipitation in the southern half of the inner domain than in the northern half during the study period (Figure 5).

Hourly precipitation totals averaged for the inner domain better illustrated the diurnal pattern of rainfall that occurred throughout the July 7-13 period. With the exception of the first rainfall event at the end of July 7 , all successive rainfall events had one or more hours exceeding $0.4 \mathrm{~mm}$, with three hours during the July 8-9 event reaching or exceeding $0.6 \mathrm{~mm}$ (Figure 6(a)). In western Kentucky (the vicinity of the CAFOs), a larger amount of average hourly precipitation was simulated during July 8-9, compared to the entire inner domain. Additionally, a bimodal pattern in hourly precipitation was present for western Kentucky with two peaks separated by 1-3 hours (Figure 6(b)). The second peak of precipitation was much smaller than the first.

(a)

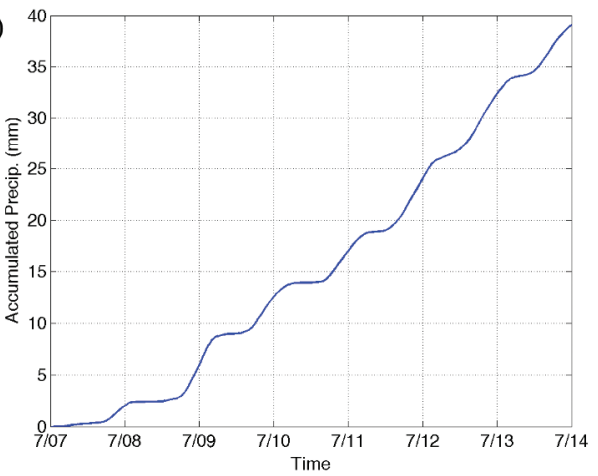

(b)

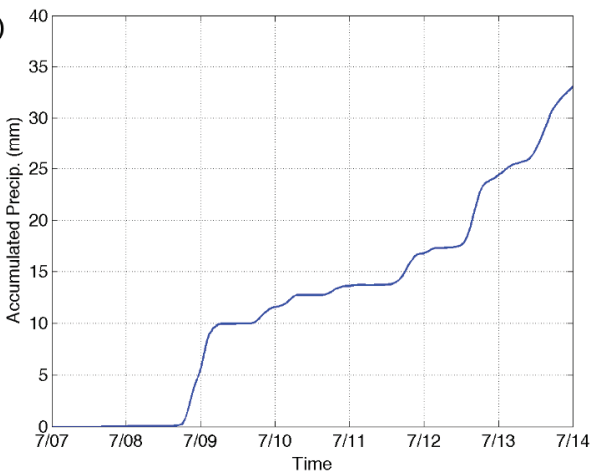

Figure 4. Simulated area average accumulated precipitation $(\mathrm{mm})$ during the July 7-13, 2012 event for (a) the inner domain and (b) the vicinity of the CAFO emission points. Dates represent 0000 UTC. 


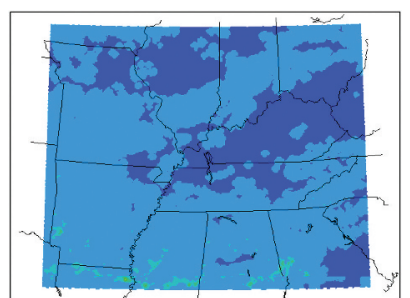

(a) 0000 UTC, July 8

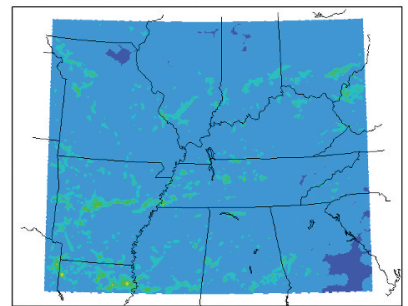

(d) 1200 UTC, July 9

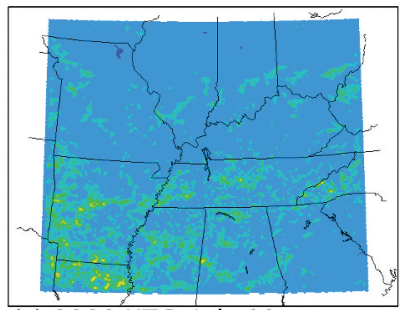

(g) 0000 UTC, July 11

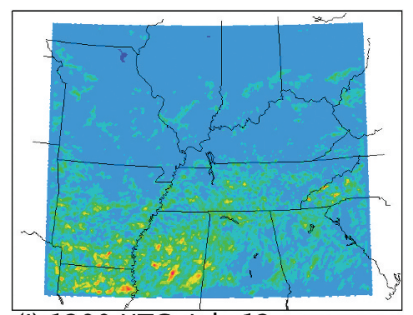

(j) 1200 UTC, July 12

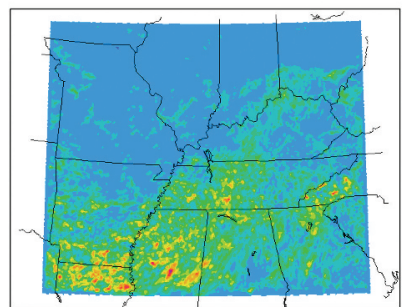

(m) 0000 UTC, July 14

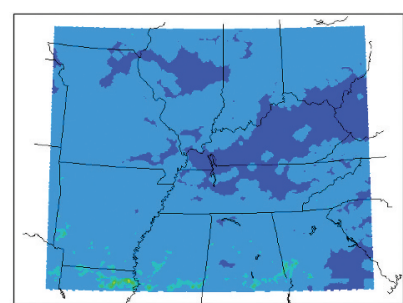

(b) 1200 UTC, July 8

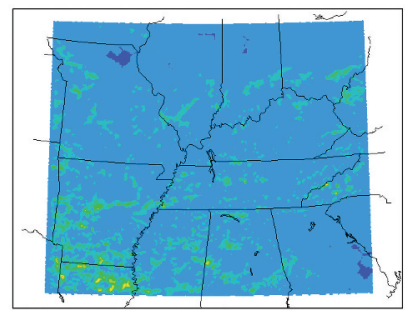

(e) 0000 UTC, July 10

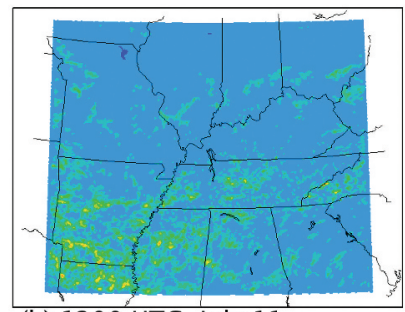

(h) 1200 UTC, July 11

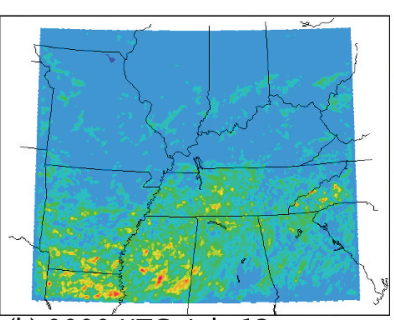

(k) 0000 UTC, July 13

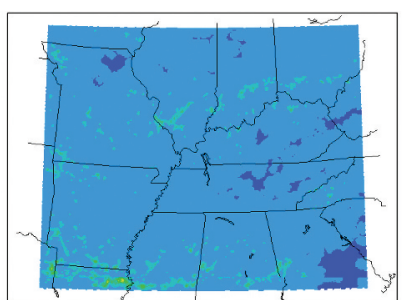

(c) 0000 UTC, July 9
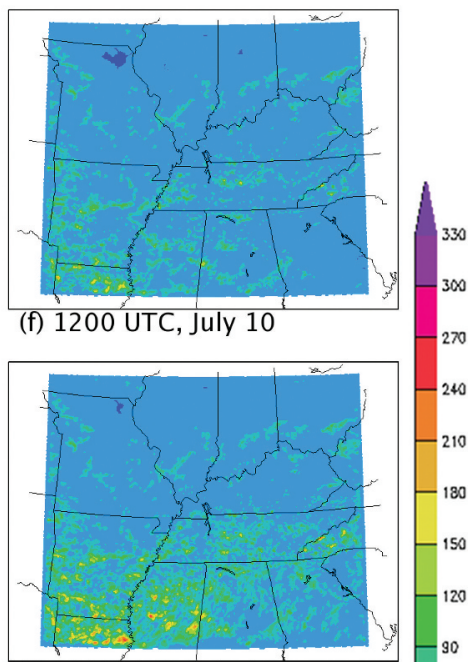

(i) 0000 UTC, July 12

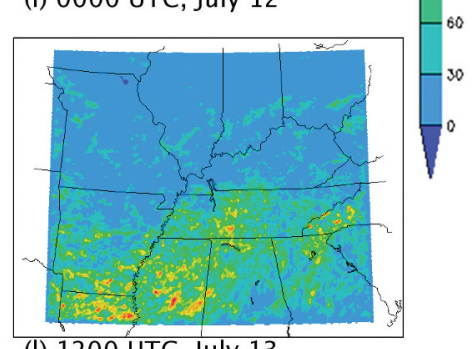

(I) 1200 UTC, July 13

330

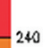

\section{0}

\section{$-180$}

\section{$-150$}

\section{$-120$}

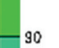

. 
(a)

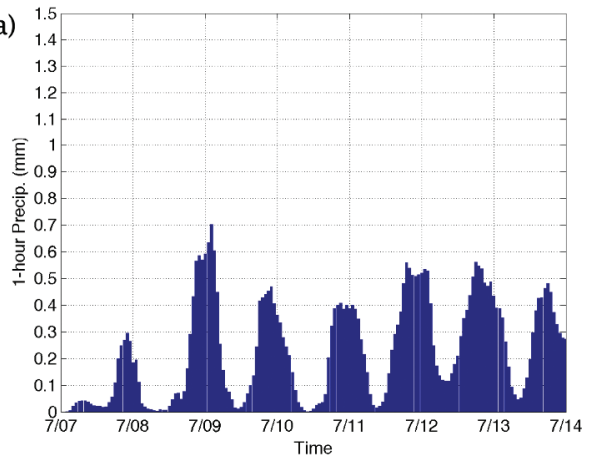

(b)

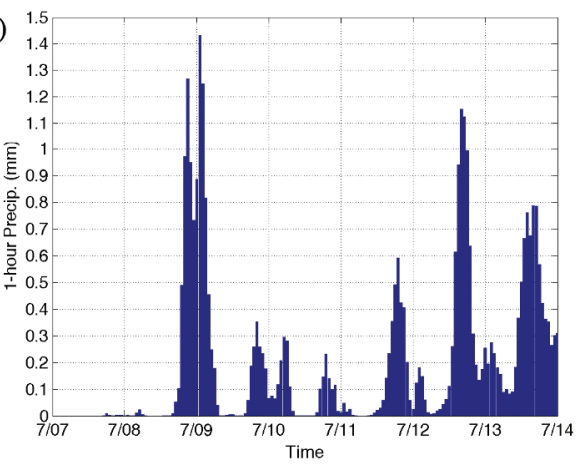

Figure 6. Area average hour precipitation totals $(\mathrm{mm})$ during the July 7-13, 2012 event for (a) the inner domain and (b) the vicinity of the CAFO emission points. Dates starts at 0000 UTC.

stretching from Ohio through southern Missouri (Figure 7(c)). By 1200 UTC, precipitation passed over the western Kentucky, resulting in its highest hourly rainfall totals for the simulated period (Figure $7(\mathrm{~d})$ ). From July 10 to July 12, rainfall remained mostly limited to the southern half of the inner domain (Figure $7(e-j)$ ). On July 13, the areas of higher precipitation totals progressed northward back into Kentucky (Figure 7(k)) and these persisted until the end of the simulation period.

\section{Control precipitation and verification}

Evaluation of the performance of the model, particularly with regards to precipitation, is important due to its localized nature and impacts on the results of this study. For this purpose, 24-hour simulated and accumulated precipitation were compared with the data from the Advanced Hydrologic Prediction Service (Advanced Hydrologic Prediction Service [AHPS], 2012) for each day. The comparison of simulated precipitation with AHPS data shows agreement and disagreement in terms of intensity and locational differences through the entire simulation period (Figure 8(a-e)). For example, comparisons on July 10 suggest that simulated precipitation occurred in the same areas as precipitation in the AHPS data. However, precipitation amounts were overestimated in southern Arkansas, Mississippi, and Alabama and underestimated along the Kentucky-Tennessee border (Figure 8(a-b)). On July 11, AHPS data suggest that most of the precipitation occurred in northern Alabama and south-central Tennessee, and this was also reflected in the model results. Precipitation totals were overestimated in areas south and west, including much of Mississippi and southeastern Arkansas (Figure 8(c-d)).

AHPS data suggest that July 12 precipitation generally occurred over the same locations as July 11 with comparable magnitudes. However, greater accumulations shifted farther south over Alabama and Mississippi. The model underestimated precipitation in these areas and overestimated amounts in much of Tennessee and western Kentucky (Figure 8(e-f)). Throughout the entire simulation, the general location of modeled precipitation agreed in most cases with AHPS estimates, but the amounts of precipitation were frequently over- or under-estimated. 


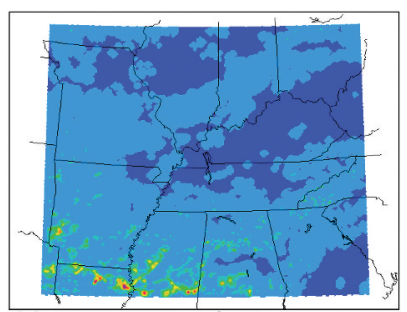

(a) 0000 UTC, July 8

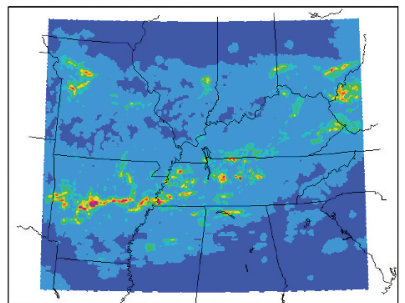

(d) 1200 UTC, July 9

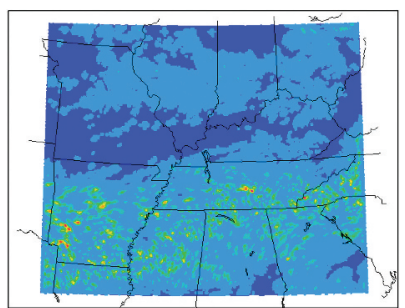

(g) 0000 UTC, July 11

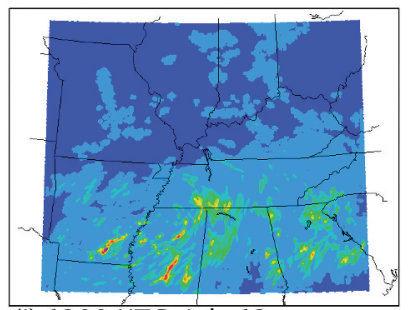

(j) 1200 UTC, July 12

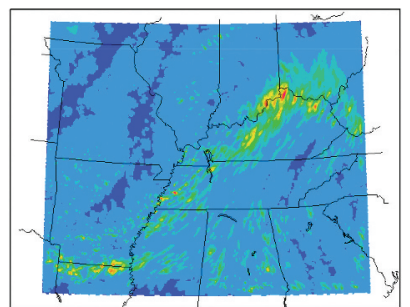

(m) 0000 UTC, July 14

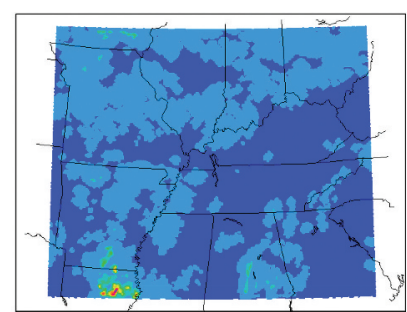

(b) 1200 UTC, July 8

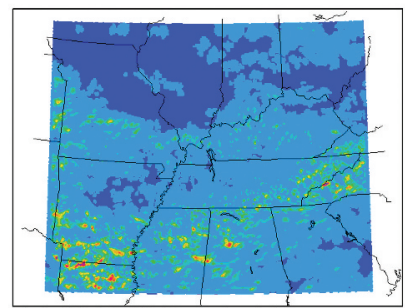

(e) 0000 UTC, July 10

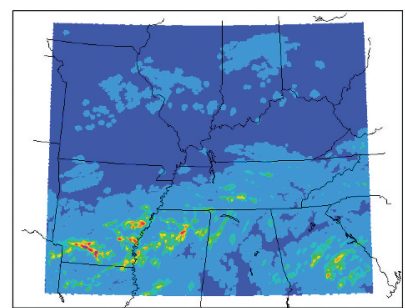

(h) 1200 UTC, July 11

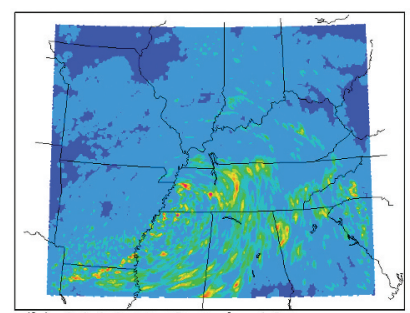

(k) 0000 UTC, July 13

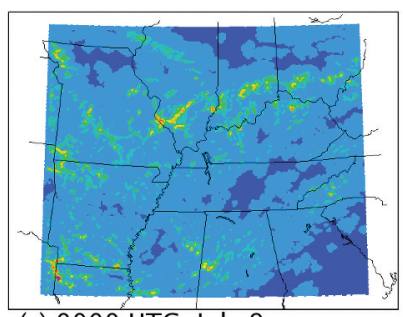

(c) 0000 UTC, July 9

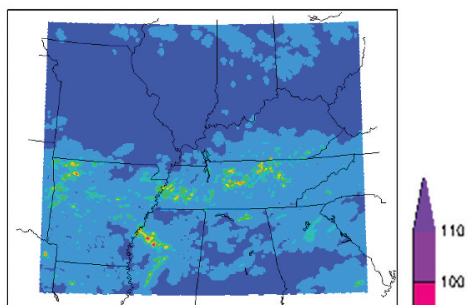

(f) 1200 UTC, July 10

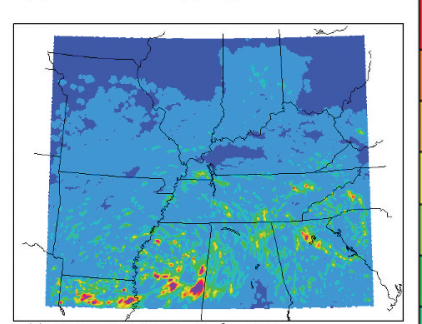

(i) 0000 UTC, July 12

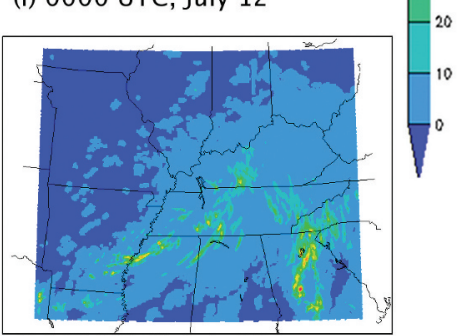

(I) 1200 UTC, July 13

\section{0}

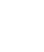




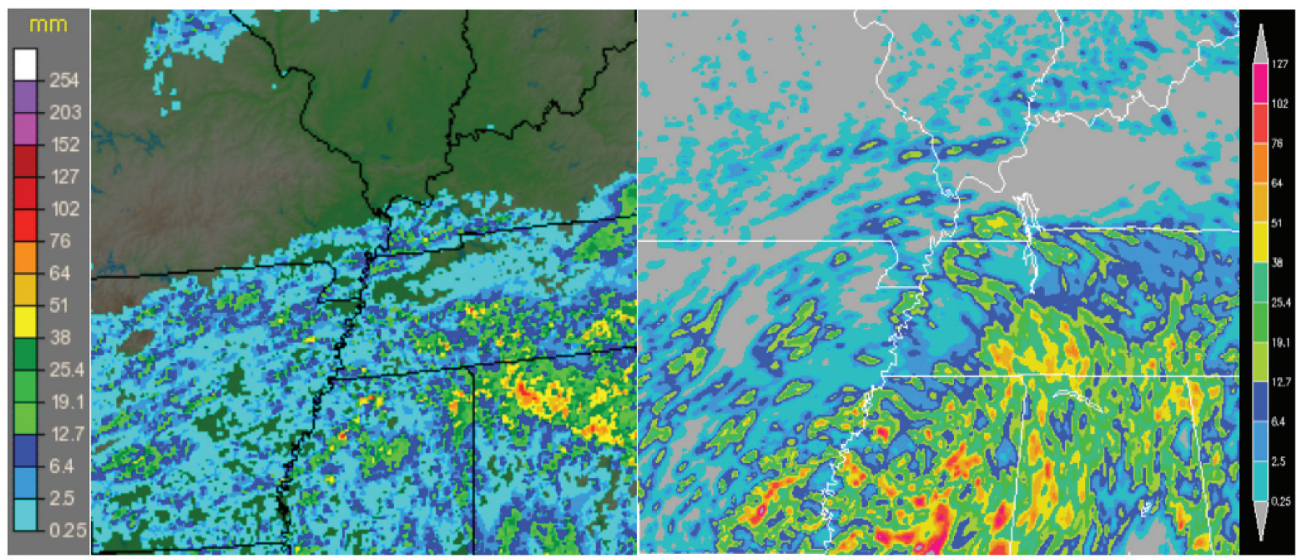

(a)

(b)

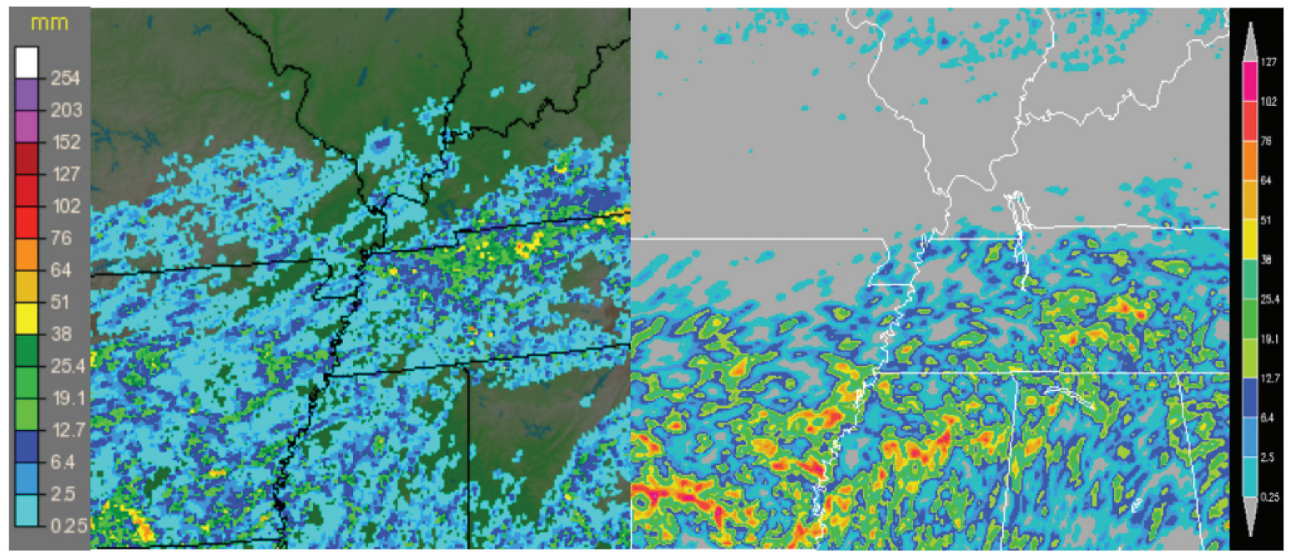

(c)

(d)

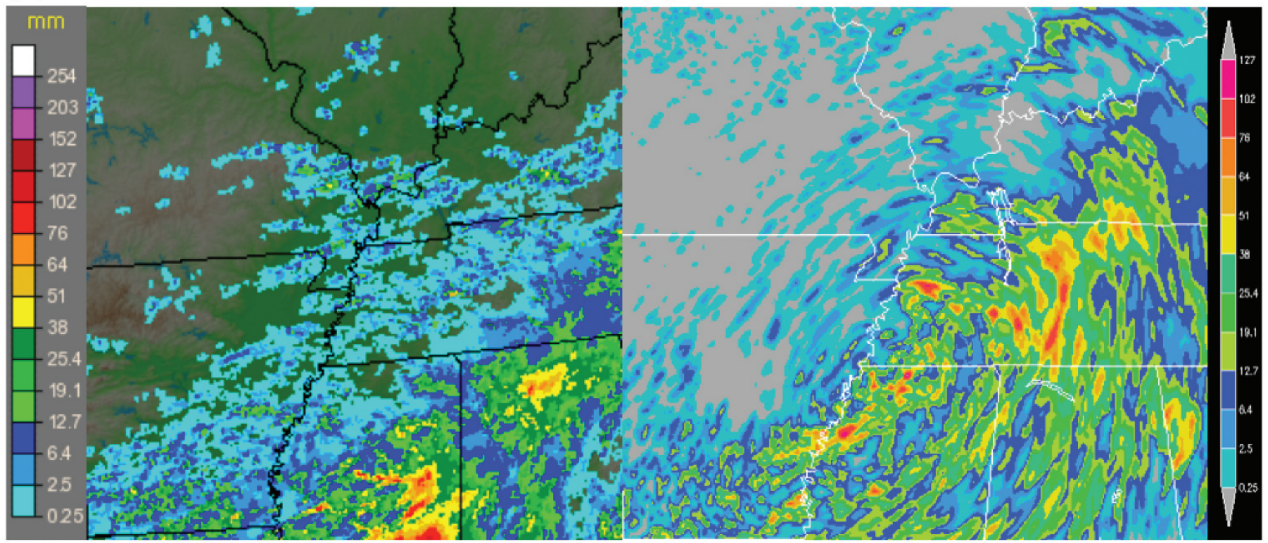

(e)

(f)

Figure 8. 24-hour accumulated precipitation $(\mathrm{mm})$ over the core of the inner domain starting at 1200 UTC on: 10 July 2012 (a) from Doppler radar estimates by the AHPS (2012), (b) from the WRF-Chem control simulation, (c) like as (a) but for on July 11, (d) like (b) but for July 11, (e) like (a) but for 12 July 2012, (f) like (b) but for 12 July 2012. 
for the inner domain, were the lowest at the surface and highest (10 $\mathrm{m} \mathrm{s}^{-1}$ on average) aloft at the 300-mb level. Wind speed peaks at the surface appeared to coincide with the peaks in hourly precipitation. However, this comparison was less noticeable in the upper levels. For the western Kentucky area (location of emissions sources), winds were much stronger aloft (near $18 \mathrm{~m} \mathrm{~s}^{-1}$ ). Wind speeds at all levels decreased below $5 \mathrm{~m} \mathrm{~s}^{-1}$ following the July 8-9 precipitation event before rebounding back to their previous speeds near the beginning of July 10. Additionally, while wind speeds at the 700 and 500-mb levels were greater than those at the surface before July 9 , it decreased near equal to surface level for the rest of the period after the July 8-9 rainfall event.

A diurnal pattern in $\mathrm{SO}_{2}$ concentrations was observed at the surface, with minima and maxima reaching near 1200 and 1800 UTC, respectively. Concentrations decreased at all levels during the stationary frontal passage and associated precipitation on July 8-9 and remained under 60 pptv for the remainder of the simulation period as rainfall continued throughout the inner domain (Figure 9(a)). The lowering of $\mathrm{SO}_{2}$ concentrations on July 8 was more pronounced for the western Kentucky and reached below 50 pptv. $\mathrm{SO}_{2}$ at the $300 \mathrm{mb}$ level rebounded to near 70 pptv on July 11, while those at the lower level of the atmosphere remained below 40 pptv. $\mathrm{SO}_{2}$ at the $300 \mathrm{mb}$ level decreased again with the onset of more precipitation in the western Kentucky on July 12 and July 13, and concentrations at the surface, $850 \mathrm{mb}$, and $700 \mathrm{mb}$ levels reached near zero (Figure $9(\mathrm{~b})$ ).

\section{Results from sensitivity experiments}

\section{Area average temporal changes}

In the first of the four sensitivity experiments conducted, $\mathrm{SO}_{2}$ emissions at the three locations representing CAFOs in western Kentucky were set to the average of surrounding emissions (EXPAVG). In the subsequent simulations, the average $\mathrm{SO}_{2}$ emissions calculated in EXPAVG were increased by 10\% (EXP10), 20\% (EXP20, and 30\% (EXP30). At the surface for the entire inner domain, the area-averaged increase in emissions from CTRL was as much as 10 pptv before July 9, and the increase ranged between 10 and 20 pptv above CTRL in all EXP simulations for the remainder of the

(a)

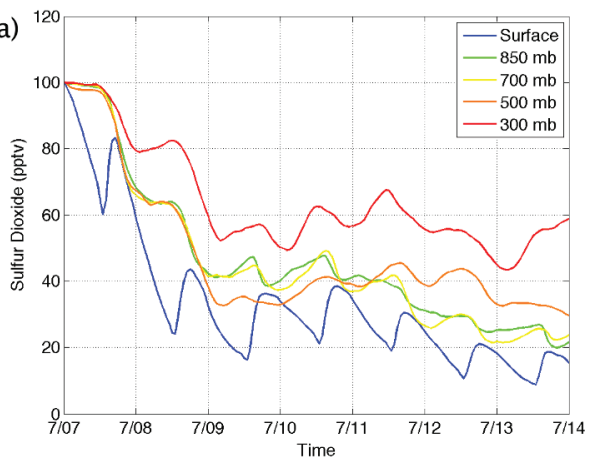

(b)

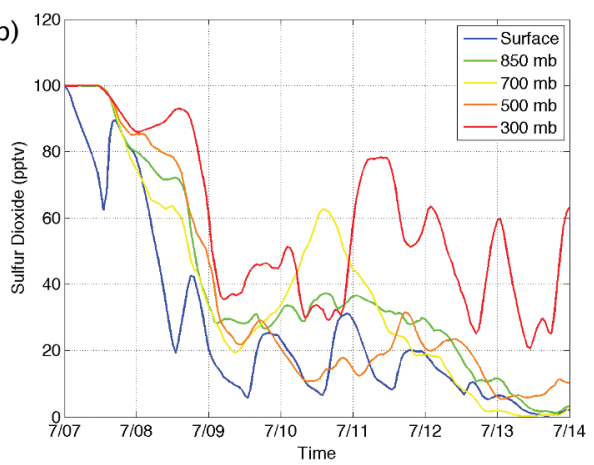

Figure 9. Area average $\mathrm{SO}_{2}$ concentrations (pptv) during the July 7-13, 2012 event for control simulation: (a) the inner domain and (b) the vicinity of the CAFO emission points. Dates represent 0000 UTC. 
(a)

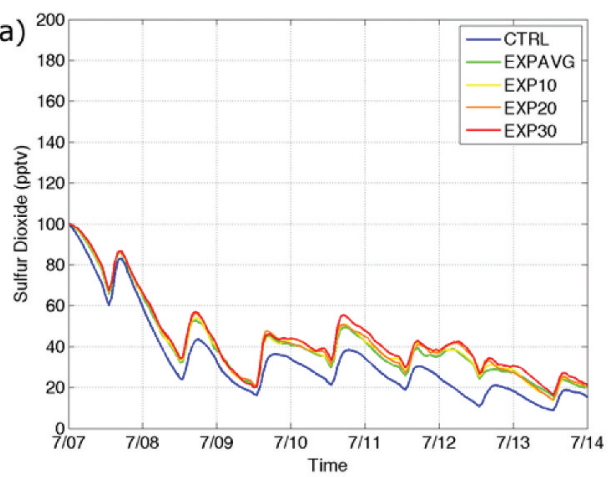

(c)

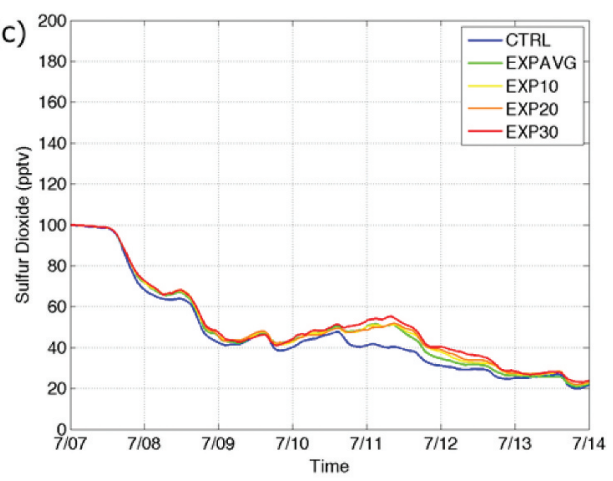

(e)

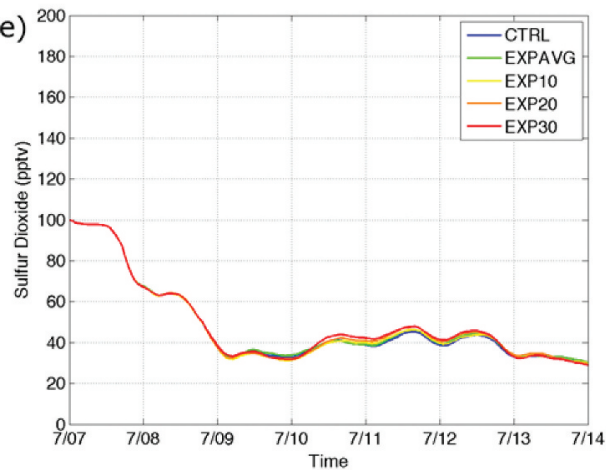

(b)

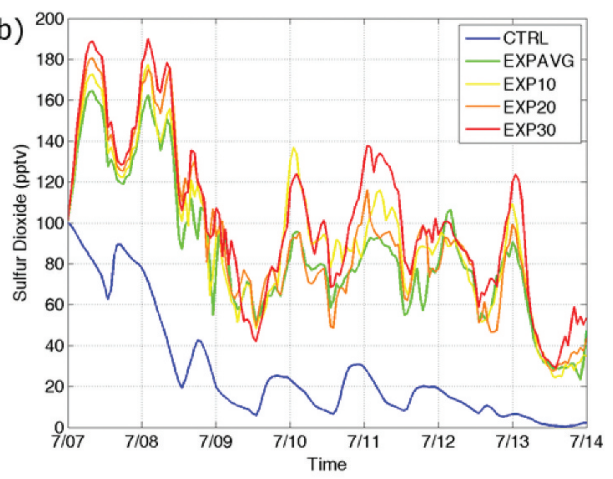

(d)

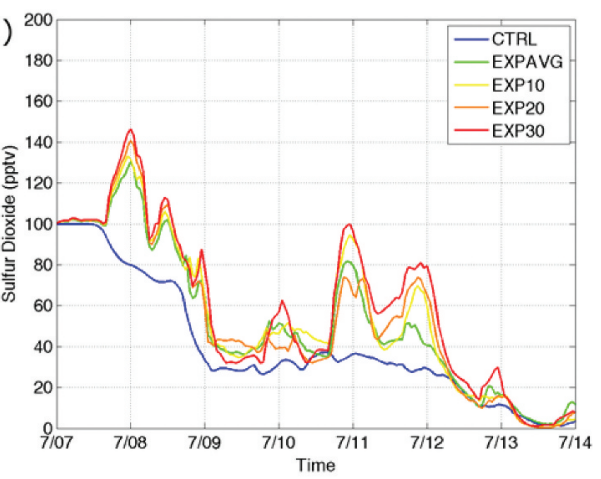

(f)

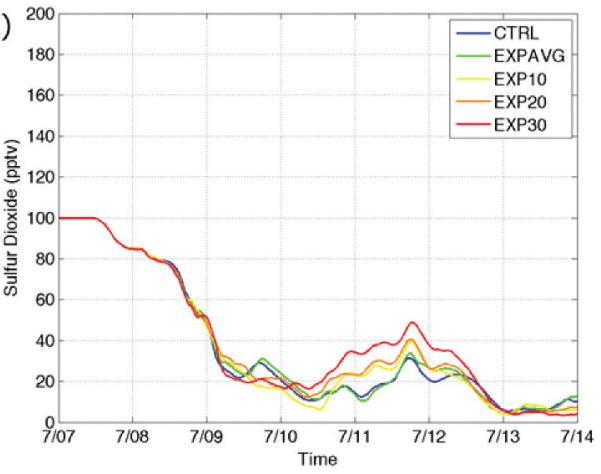

Figure 10. Area average $\mathrm{SO}_{2}$ concentrations (pptv) at the surface for the emissions change simulations during the July 7-13, 2012 event over (a) the inner domain, (b) the vicinity of the CAFO emission sources, c) as 'a' but for $850 \mathrm{mb}$ level, d) as 'b' but for $850 \mathrm{mb}$ level, e) as 'a' but for $700 \mathrm{mb}$ level, and f) as 'b' but for $700 \mathrm{mb}$ level.

period (Figure 10(a)). Near to the emissions change locations, the increase in $\mathrm{SO}_{2}$ from CTRL was much greater in all EXP simulations, with area-averaged increases of up to 110 pptv from CTRL occurring at 0000 UTC on several days (Figure 10(b)). For most of the simulation period, EXPAVG had the lowest and EXP30 had the highest concentrations. However, there were brief fluctuations of these concentration on July 9 and July 12 (Figure 10(b)). These fluctuations coincided with increased precipitation in 
western Kentucky on these days (cf., Thornton et al., 1997; Tu et al., 2004; Wang et al., 2011).

At the $850 \mathrm{mb}$ level, there was less of a difference between CTRL and the emissions change simulations than near the surface, and the diurnal pattern of concentrations was less pronounced across the inner domain (Figure 10(c)). The difference between EXP30 and CTRL remained at 10 pptv or less until July 10 and then increased to near 20 pptv, with EXPAVG, EXP10, and EXP20 having smaller changes from CTRL. The areaaveraged concentrations of $\mathrm{SO}_{2}$ for the area near the emissions change locations were again higher than those for the entire inner domain, reaching as much as $70 \mathrm{pptv}$ above CTRL for the EXP30 simulation at 0000 UTC on July 8 and July 11 (Figure 10(d)).

There were lower differences between the emissions change simulations and CTRL above the $850 \mathrm{mb}$ level. Over the entire inner domain, there was an average increase in $\mathrm{SO}_{2}$ concentrations of up to 5 pptv on July 10 and 11 between all simulations, but the average concentration between them matched closely during the rest of the period at the $700 \mathrm{mb}$ (Figure 10(e)), $500 \mathrm{mb}$ (not shown), and $300 \mathrm{mb}$ levels (not shown). For the area in the vicinity of the emissions change locations, there was little difference in $\mathrm{SO}_{2}$ concentrations between simulations at the $700 \mathrm{mb}$ level (Figure 10(f)) and higher until July 9. At the $700 \mathrm{mb}$ level, the local area-averaged concentration for CTRL was up to 20 pptv higher than those for the emissions increase simulations, but there was little difference between all simulations again by 1200 UTC on July 10 (Figure 10(f)). The most area-averaged changes in $\mathrm{SO}_{2}$ at the $500 \mathrm{mb}$ level occurred between 1200 UTC on July 10 and 1200 UTC on July 12, with concentrations in the EXP30 simulations being up to 20 pptv greater than CTRL.

\section{Spatial changes}

At the surface at 0000 UTC on July 8, the largest increases of $\mathrm{SO}_{2}$ concentrations from CTRL in the EXP simulations were at least 1,000 pptv near the emissions change locations representing the CAFOs in western Kentucky (Figures 11 and 12). These increased emissions had spread to the north of their sources into Indiana and Illinois due to southerly winds, with the difference in concentrations from CTRL decreasing rapidly with distance. Changes from CTRL at the $850 \mathrm{mb}$ level were similar to those at the surface in all EXP simulations (Figures 11 and 12).

Figure 13(a-h) shows dispersion and concentration of $\mathrm{SO}_{2}$ at the surface and at 850 mb level. By 1200 UTC on July 8 at the surface, the area of increased $\mathrm{SO}_{2}$ concentrations had expanded farther toward the north (Figure 13(a)). The increases were greater than 100 pptv compared to CTRL and were spreading into southern Illinois and Indiana in all EXP simulations at the surface (Figure 13(a,c,e,g)). Another area of $\mathrm{SO}_{2}$ increase of up to 900 pptv appeared along the northeastern boundary of the inner domain. Increases of up to $300 \mathrm{pptv}$ at the $850 \mathrm{mb}$ level were also present in the same areas as those at the surface, and extended along the border of Kentucky and Indiana and into western Ohio (Figure 13(b,d,f,h)).

Emissions began to disperse toward the south into Tennessee with northerly winds at 0000 UTC on July 9 near the surface (not shown). Increased concentrations were mostly restricted to narrow bands at the surface, while those at the $850 \mathrm{mb}$ level were more widespread, exceeding 900 pptv in EXP30-CTRL, 700 pptv in EXP20-CTRL, and 500 pptv in EXP10-CTRL. By 1200 UTC (Figure 14(a-h)), emissions continued to disperse 


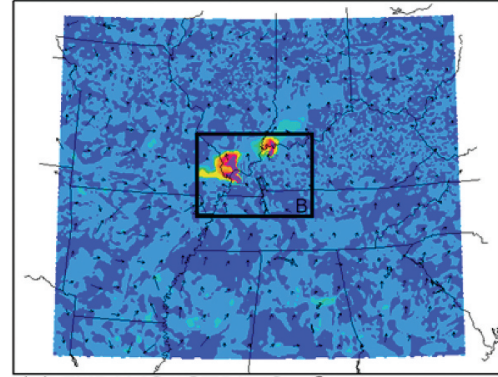

(a) EXPAVG-CTRL, Surface

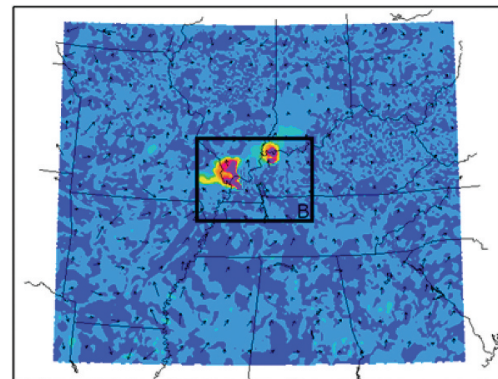

(c) EXP10-CTRL, Surface

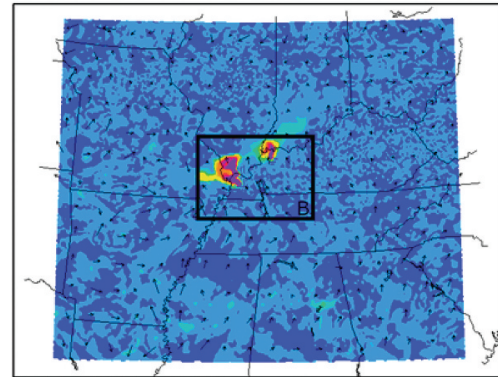

(e) EXP20-CTRL, Surface

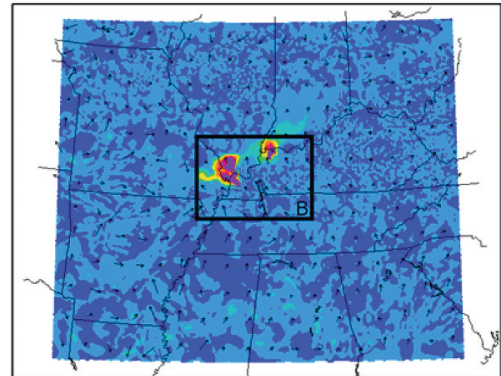

(g) EXP30-CTRL, Surface

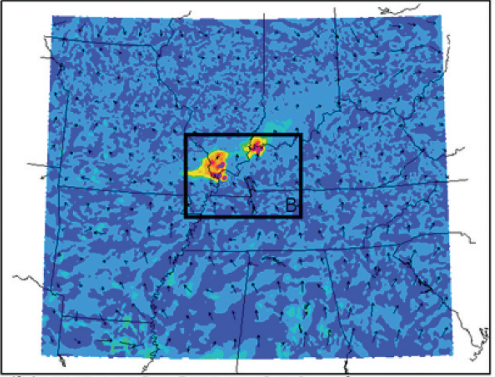

(b) EXPAVG-CTRL, $850 \mathrm{mb}$

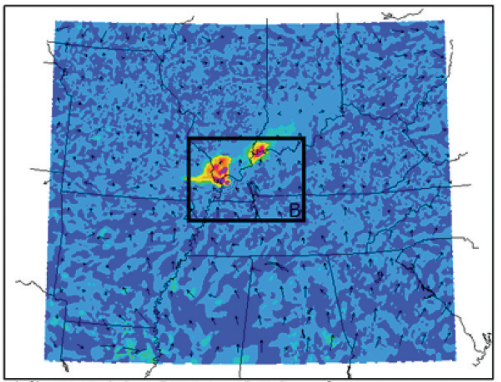

(d) EXP10-CTRL, $850 \mathrm{mb}$

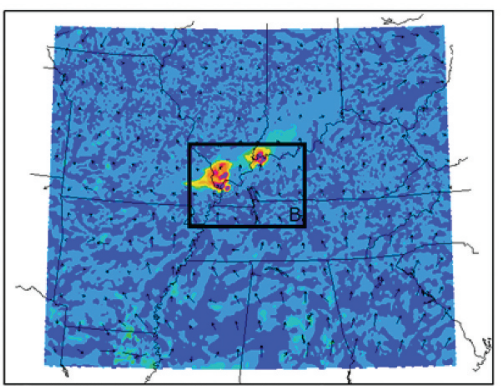

(f) EXP20-CTRL, $850 \mathrm{mb}$

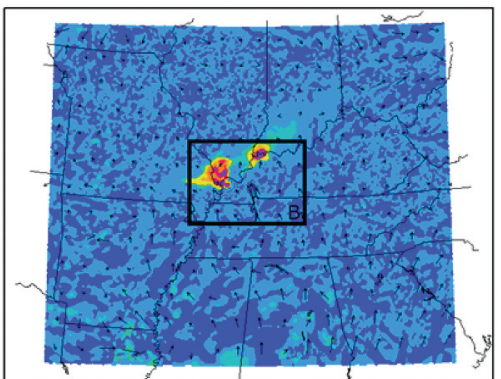

(h) EXP30-CTRL, $850 \mathrm{mb}$
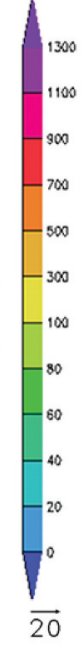

Figure 11. Changes in $\mathrm{SO}_{2}$ concentrations (pptv) from CTRL and horizontal wind vectors $\left(\mathrm{m} \mathrm{s}^{-1}\right)$ at the surface and $850 \mathrm{mb}$ levels within the inner domain for each of the emissions increase simulations at 0000 UTC on 8 July 2012. The areas enclosed by box B are expanded in Figure 12.

southward in all EXP simulations, and increased $\mathrm{SO}_{2}$ concentrations were less widespread in EXP30 than in the other simulations. At the $850 \mathrm{mb}$ level, there was small 


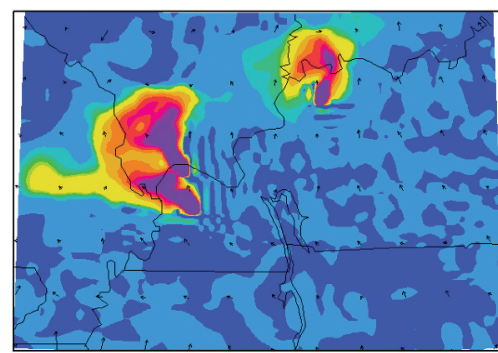

(a) EXPAVG-CTRL, Surface

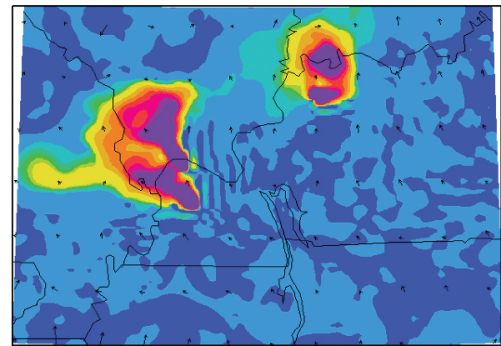

(c) EXP10-CTRL, Surface

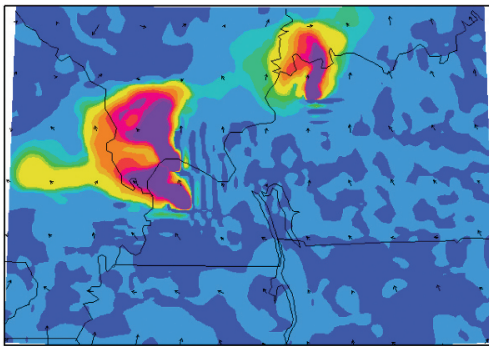

(e) EXP20-CTRL, Surface

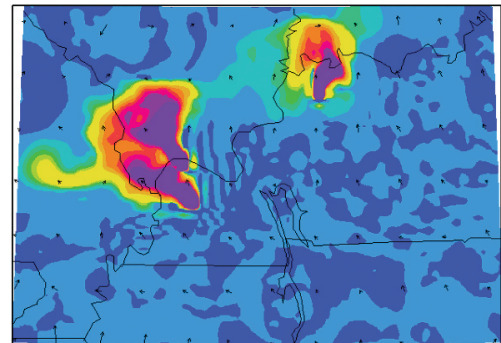

(g) EXP30-CTRL, Surface

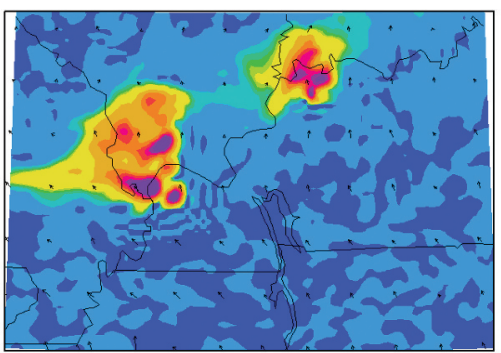

(b) EXPAVG-CTRL, $850 \mathrm{mb}$

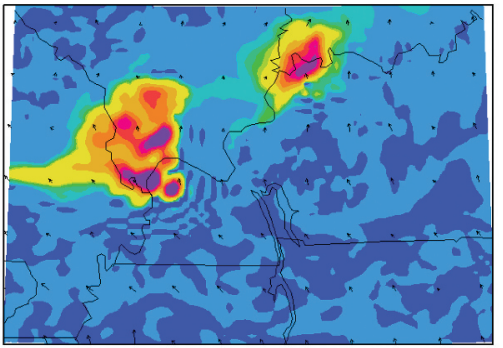

(d) EXP10-CTRL, $850 \mathrm{mb}$

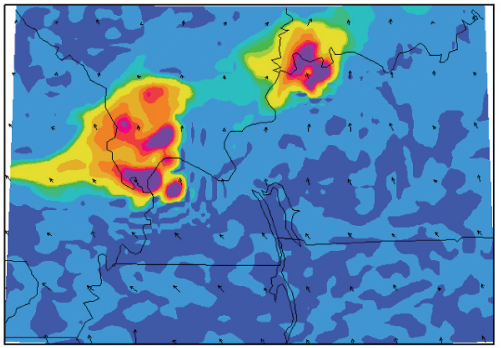

(f) EXP20-CTRL, $850 \mathrm{mb}$

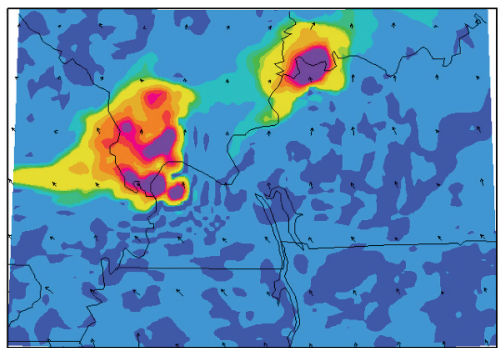

(h) EXP30-CTRL, $850 \mathrm{mb}$
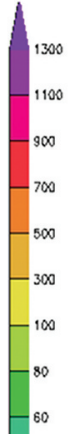

$-40$

$-20$

$-1$

$\overrightarrow{20}$

Figure 12. Changes in $\mathrm{SO}_{2}$ concentrations (pptv) from CTRL and horizontal wind vectors $\left(\mathrm{m} \mathrm{s}^{-1}\right)$ at the surface and $850 \mathrm{mb}$ levels within box B from Figure 11 .

increase in concentrations for EXP30-CTRL. However, increases of up to 300 pptv for EXP20-CTRL and up to 60 pptv for EXP10-CTRL and EXPAVG-CTRL were also found (Figure 14(b,d,f,h)). 


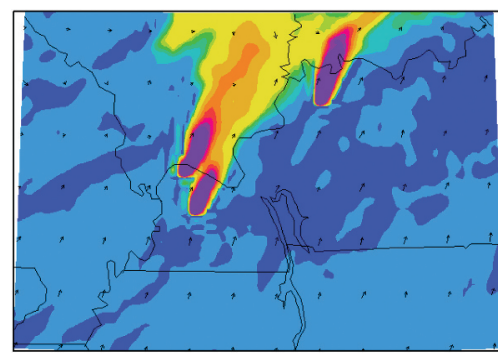

(a) EXPAVG-CTRL, Surface

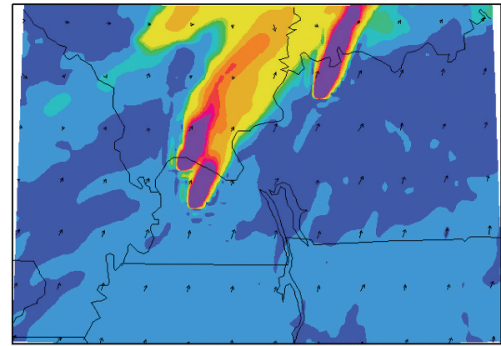

(c) EXP10-CTRL, Surface

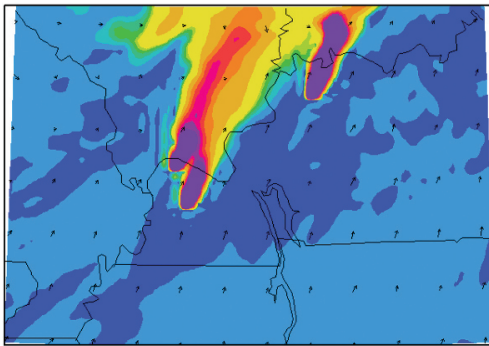

(e) EXP20-CTRL, Surface

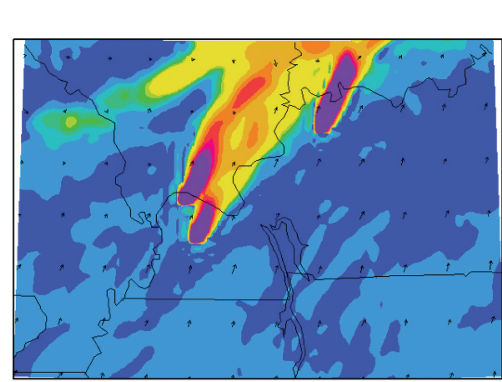

(g) EXP30-CTRL, Surface

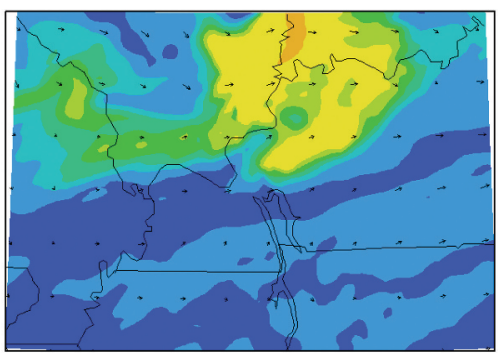

(b) EXPAVG-CTRL, $850 \mathrm{mb}$

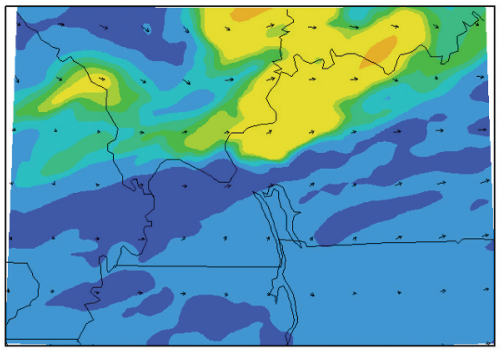

(d) EXP10-CTRL, $850 \mathrm{mb}$

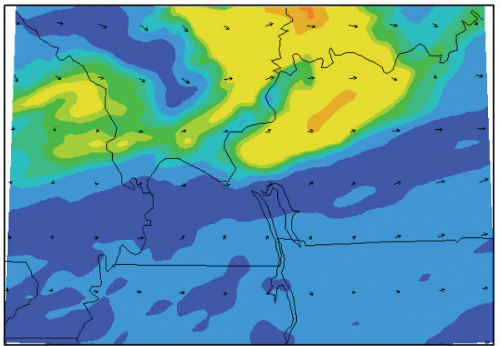

(f) EXP20-CTRL, $850 \mathrm{mb}$

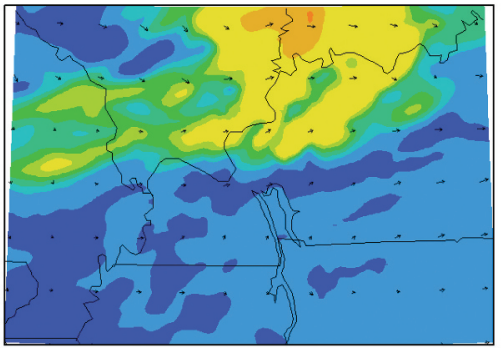

(h) EXP30-CTRL, $850 \mathrm{mb}$
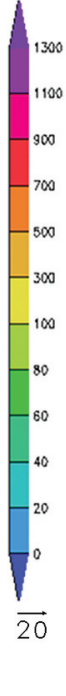

\begin{abstract}
(g) EX30-CTRL, Surface
\end{abstract}
Figure 13. Changes in $\mathrm{SO}_{2}$ concentrations (pptv) from CTRL and horizontal wind vectors $\left(\mathrm{m} \mathrm{s}^{-1}\right)$ at the surface and $850 \mathrm{mb}$ levels at 1200 UTC on 8 July 2012.

At 0000 UTC on July 10, the CAFO emitted $\mathrm{SO}_{2}$ began to travel toward the southsouthwest. While $\mathrm{SO}_{2}$ concentrations exceeding 700 pptv above CTRL remained limited 
to the emission locations, concentrations up to 500 pptv spread into parts of eastern Missouri from the western emission locations, and those from the location to the east continued to travel toward the south into the Land Between the Lakes area in EXPAVG and EXP10. In EXP20 and EXP30, localized concentrations around the emission locations were higher, but the extent of the spatial dispersion was more limited. For the area near the emission sources at the $850 \mathrm{mb}$ level, increased concentrations were transporting toward the south-southwest, but were less widespread than those at the surface.

Surface emissions at 1200 UTC on July 10 remained limited to western Kentucky and southern Illinois in EXPAVG and EXP10. In EXP20 and EXP30, emissions traveled more toward the west into eastern Missouri with a larger area of $\mathrm{SO}_{2}$ concentrations up to 300 pptv above CTRL. At the $850 \mathrm{mb}$ level, there was a band of increased concentrations to the west of the emission locations in eastern Missouri and northern Arkansas. The location of the greatest increase within the band differed between simulations, with the greatest increase exceeding 100 pptv above CTRL over eastern Missouri in EXP10, across the state boundary between Missouri and Arkansas in EXPAVG, and over northern Arkansas only in EXP20 and EXP30.

Emissions at the surface transported toward the west from all locations at 0000 UTC and 1200 UTC on July 11, with $\mathrm{SO}_{2}$ concentrations exceeding 100 pptv above CTRL in southern Illinois and southeastern Missouri in all EXP simulations. In EXP20 and EXP30, emissions also entered far northeastern Arkansas. At the $850 \mathrm{mb}$ level, $\mathrm{SO}_{2}$ concentrations in all EXP simulations were more widespread than those at the surface, with increased emissions transported farther into northeastern Arkansas in all cases. The earlier emissions to the east had drifted southwest into eastern Kentucky, western Virginia, and northeastern Tennessee at both the surface and $850 \mathrm{mb}$ levels, with the highest increases from CTRL continuing to exceed 100 pptv.

Surface emission dispersion turned more toward the north and northwest from their sources at 0000 UTC on July 12. Emissions in EXPAVG were limited to southern Illinois, but those in EXP10, EXP20, and EXP30 also entered southeastern Missouri. There were more differences between emission sources at the $850 \mathrm{mb}$ level, as only emissions from the easternmost location were apparent in EXPAVG and EXP10. Emissions originating from the western locations were more visible in EXP20 and EXP30 as concentrations exceeding 100 pptv above CTRL and spreading through the southeastern Missouri.

Emissions transported farther to the north and northwest into Illinois and Missouri at 1200 UTC on July 12 (Figure 15(a-h)), with concentrations exceeding 80 pptv above CTRL in these areas and in all EXP simulations (Figure 15(a,c,e,g)). This expansion of increased $\mathrm{SO}_{2}$ concentrations from CTRL is likely due, in part, to precipitation moving southward from the emission locations at this time. There was also an increase of up to 300 pptv above CTRL in Ohio and part of Indiana coincident with the northern boundary of the inner domain, and it is uncertain if this was related to the emissions. At the $850 \mathrm{mb}$ level, the counterclockwise rotation of winds caused emissions to turn toward the southwest and moved across Missouri with smaller increases of concentration in EXP20 and EXP30, compared to CTRL (Figure 15(b,d,f,h)).

At 0000 UTC on July 13, the emissions plume extended toward the west into southern Illinois and southeastern Missouri at the surface in all EXP simulations. Additionally, emissions remained more spatially compact than at earlier times, with high 


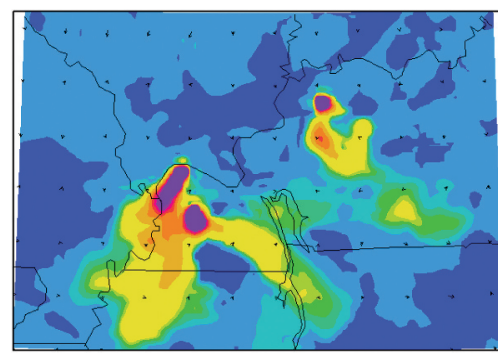

(a) EXPAVG-CTRL, Surface

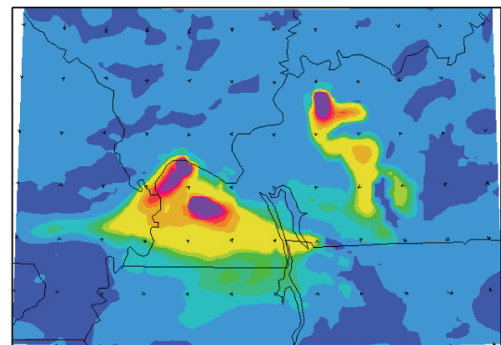

(c) EXP10-CTRL, Surface

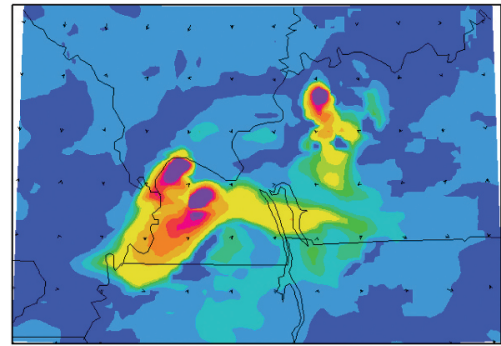

(e) EXP20-CTRL, Surface

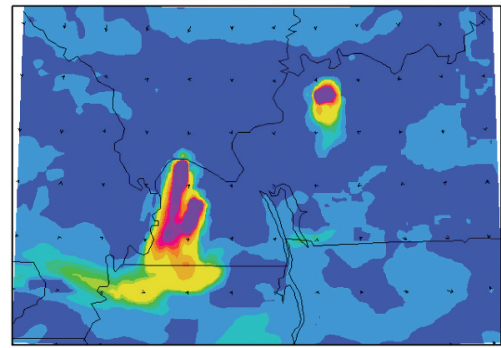

(g) EXP30-CTRL, Surface

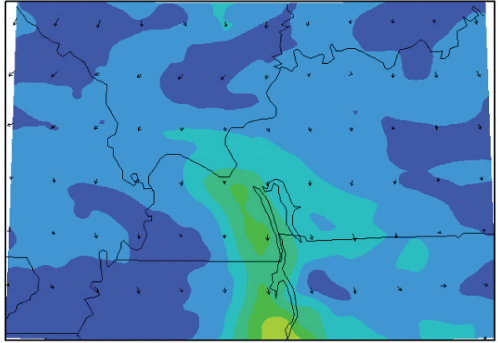

(b) EXPAVG-CTRL, $850 \mathrm{mb}$

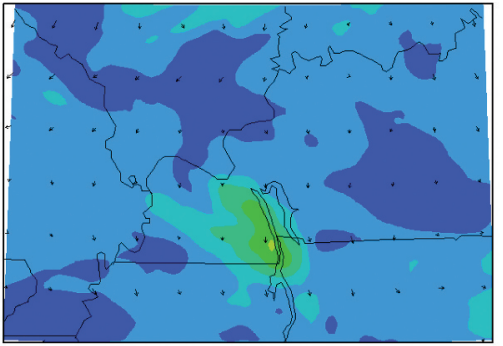

(d) EXP10-CTRL, $850 \mathrm{mb}$

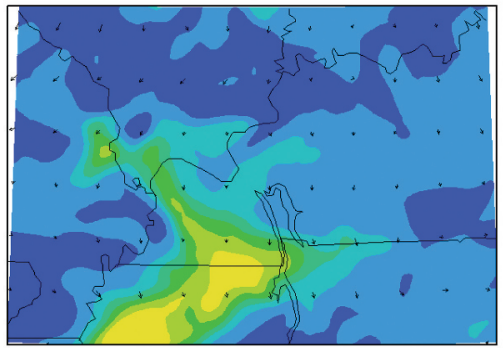

(f) EXP20-CTRL, $850 \mathrm{mb}$

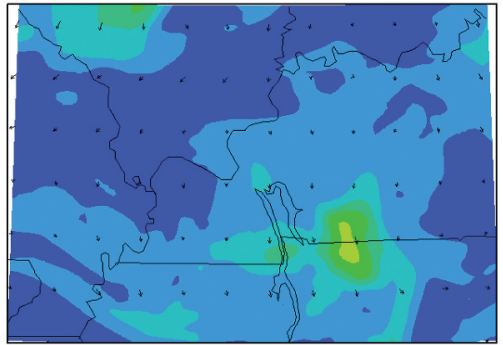

(h) EXP30-CTRL, $850 \mathrm{mb}$

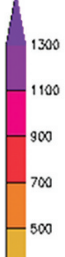

Figure 14. Changes in $\mathrm{SO}_{2}$ concentrations (pptv) from CTRL and horizontal wind vectors $\left(\mathrm{m} \mathrm{s}^{-1}\right)$ at the surface and $850 \mathrm{mb}$ levels at 1200 UTC on 9 July 2012.

concentrations forming narrow bands. The highest concentrations exceeding 1,000 pptv above CTRL also extended farther from their sources than previously. 
By 1200 UTC on July 13 and through 0000 UTC on July 14, emissions did not extend very far from their sources at the surface, as $\mathrm{SO}_{2}$ concentrations quickly lowered with distance. At the $850 \mathrm{mb}$ level, the emissions around their sources were completely absent, but the prior emissions to the west were still present, reaching up to 300-500 pptv greater than CTRL, in areas oriented along the northerly flow of wind.

\section{Aerial extent of $\mathrm{SO}_{2}$ dispersion}

The spatial extent of increased $\mathrm{SO}_{2}$ concentrations around the emissions locations varied throughout the seven-day period. In this section, the changes in the size of area affected by increased $\mathrm{SO}_{2}$ concentrations during the different experimental simulations and the relation to precipitation are discussed. In the area close to the three specific emission locations in the western Kentucky, the size of increased concentrations of $>100$ pptv over CTRL was as high as about $10,000 \mathrm{~km}^{2}$ in all simulations prior to increased precipitation on each day. The size decreased during each precipitation event followed by expansions of area after the end of precipitation (Figure 16(a)) (cf., Thornton et al., 1997; Tu et al., 2004; Wang et al., 2011).

In the area near the changed emission locations, at the $850 \mathrm{mb}$ level, the area of $\mathrm{SO}_{2}$ concentrations $>100$ pptv above CTRL increased to between 9,000 and $11,000 \mathrm{~km}^{2}$ in all EXP simulations on July 8 . They decreased to near zero after the precipitation early on July 9 with the exception of EXP20. The two peaks in the area of increased $\mathrm{SO}_{2}$ were reflected, to an extent, in the CAFO area on July 10 and 11, and it disappeared after the larger amount of precipitation on July 12 (Figure 16(b)). There was little to no area with increases in $\mathrm{SO}_{2}$ concentrations at least $100 \mathrm{pptv}$ for EXP-CTRL above the $850 \mathrm{mb}$ level.

\section{Discussions}

The WRF-Chem applications and simulated of $\mathrm{SO}_{2}$ dispersion over a geographic area under wet and dry atmospheric conditions generally agreed with our conceptual understanding. Results showed that with wet and dry conditions $\mathrm{SO}_{2}$ concentrations were lower and higher, respectively. In addition, simulations suggest background $\mathrm{SO}_{2}$ concentrations were greater at higher levels than those closer to the surface and is linked to reaction between $\mathrm{SO}_{2}$ and precipitation in the lower levels. It is found that increased emissions from the CAFOs resulted in wider dispersion except during higher wind speeds.

As noted previously, that there is lack of studies focusing on applications of the WRFChem for agricultural $\mathrm{SO}_{2}$ emissions. However, a study by Bela et al. (2016) showed lower concentration of $\mathrm{SO}_{2}$ at lower level of the atmosphere. This is somewhat similar to our control simulations for this study (Winchester, 2015). In an observational data-based study Thornton et al. (1996) found increasing $\mathrm{SO}_{2}$ level with increasing height over the north Pacific. Tu et al. (2004) investigated long-range transport of $\mathrm{SO}_{2}$ from the east Asia to the central North Pacific. They have found $\mathrm{SO}_{2}$-enriched layers above the boundary layer with low water vapor. Based on additional analysis of data they suggested that cloud processes helped to remove $\mathrm{SO}_{2}$ and cloud free condition can assist $\mathrm{SO}_{2}$ dispersion to longer distance (Tu et al., 2004). Our study also found similar results where dry conditions helped dispersion of $\mathrm{SO}_{2}$ to longer distances while precipitation restricted dispersion.

Loughner et al. (2011) used WRF model to simulate meteorological data which were fed to Community Multi-Scale Air Quality (CMAQ) to simulate pollutant transport and 


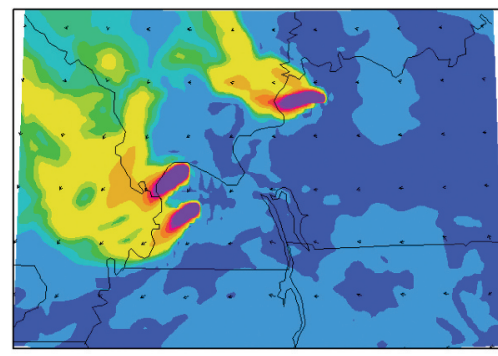

(a) EXPAVG-CTRL, Surface

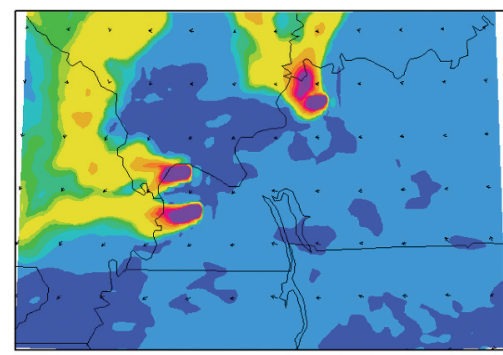

(c) EXP10-CTRL, Surface

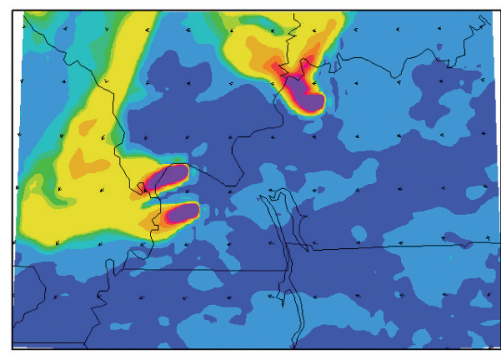

(e) EXP20-CTRL, Surface

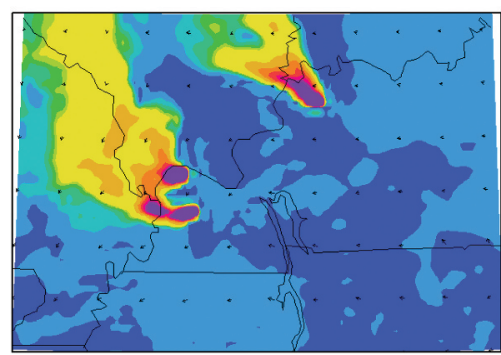

(g) EXP30-CTRL, Surface

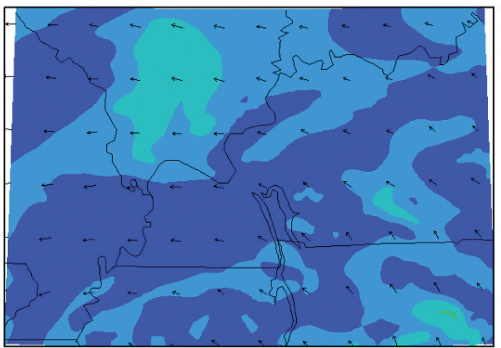

(b) EXPAVG-CTRL, $850 \mathrm{mb}$

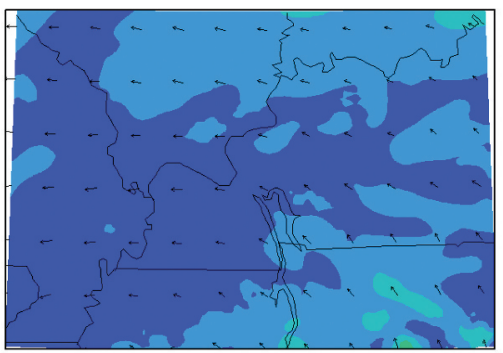

(d) EXP10-CTRL, $850 \mathrm{mb}$

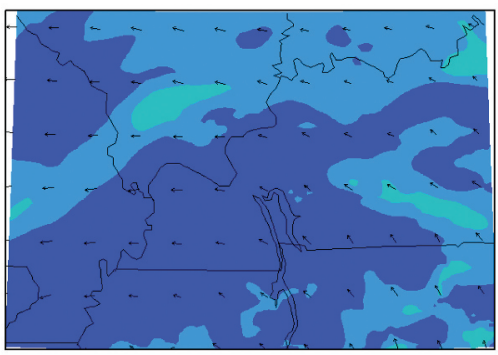

(f) EXP20-CTRL, $850 \mathrm{mb}$

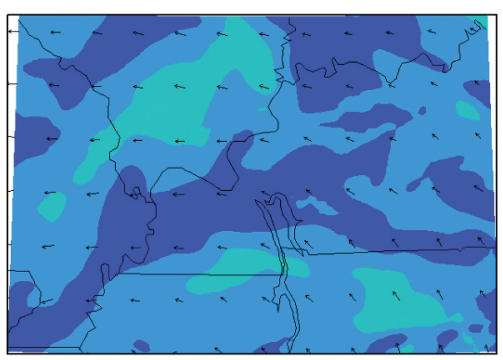

(h) EXP30-CTRL, $850 \mathrm{mb}$

Figure 15. Changes in $\mathrm{SO}_{2}$ concentrations (pptv) from CTRL and horizontal wind vectors $\left(\mathrm{m} \mathrm{s}^{-1}\right)$ at the surface and $850 \mathrm{mb}$ levels at 1200 UTC on 12 July 2012.

conversion of $\mathrm{SO}_{2}$ to sulfate in the Washington DC-Baltimore metropolitan area. They have found that increased model resolution improved simulated results compared to observations. These simulations also show an increased rate of oxidation of $\mathrm{SO}_{2}$ to sulfate 
a)
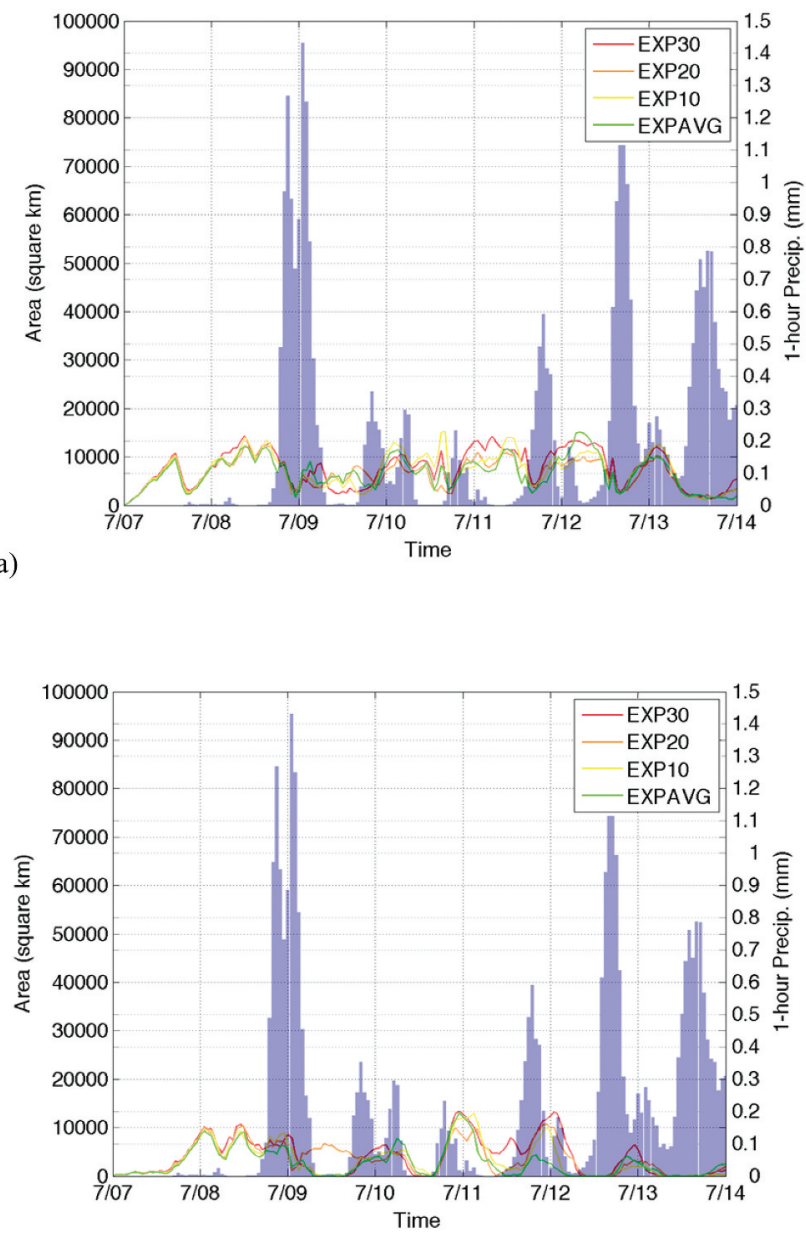

b)

Figure 16. a) The area $\left(\mathrm{km}^{2}\right)$ of the vicinity of the CAFO emission locations with $\mathrm{SO}_{2}$ concentrations exceeding 100 pptv above CTRL at the surface throughout the period in all EXP simulations (colored lines) and the area-averaged hourly precipitation for the same area in CTRL (blue bars). Dates represent 0000 UTC. b) Same as "a)" but for $850 \mathrm{mb}$.

aerosols. Previously, from observational data, Thornton et al. (2002) found higher concentration of $\mathrm{SO}_{2}$ in the lower $1000 \mathrm{~m}$ and rapid decline above this altitude. These observations are similar to the findings by Ukhov et al. (2020) for different regions of the Middle East. During a multi-year WRF-Chem based simulations for the northern China Plains Liu et al. (2018) found that reduction in $\mathrm{SO}_{2}$ emission is responsible for increased $\mathrm{NH}_{3}$. They have demonstrated that reduction in sulfate formation led to significant weakening of ammonium sulfate formation and increased in gas phase $\mathrm{NH}_{3}$ formation. From a subcontinental-scale applications of WRF-Chem over east Asia, Zhong et al. 
(2016) found that accuracy of $\mathrm{SO}_{2}$ simulations varies from region to region and are season dependent.

In short, the WRF-Chem based simulated results related to vertical distribution and the nature of dispersion of $\mathrm{SO}_{2}$ in our study are comparable to other studies. From the above discussions it is also evident that a vast majority of the $\mathrm{SO}_{2}$ emission related studies were focused on its large-scale dispersions and in some cases its interactions with other chemical species. These findings apply to both observational data- and model-based research. In addition, almost none of these research were focused on agricultural emissions. In other words, our study is an important step for further applications of the WRFChem model for agricultural and specifically for $\mathrm{SO}_{2}$ emissions from CAFOs and its local and regional dispersions.

\section{Conclusions}

Air pollution is well known for negatively impacting human health. These impacts include cardiovascular and respiratory health. In this context, the objective of this research was to simulate and analyze dispersion of the $\mathrm{SO}_{2}$ emissions from CAFOs during wet and dry periods. In this study, $\mathrm{SO}_{2}$ dispersions were analyzed horizontally and vertically during a one-week period that includes both wet and dry periods in July 2012. Due to the chemical reaction of $\mathrm{SO}_{2}$ with water vapor, the assumption was that the presence of precipitation over the emission locations would result in changes to atmospheric concentration of $\mathrm{SO}_{2}$ in their vicinity, and that the geographic spread of emissions would change during precipitation in comparison to drier conditions. A control simulation and four emissions change (experiment or EXP) simulations (each were 7 days long) were performed using the WRF-Chem model. $\mathrm{SO}_{2}$ emissions at these locations were increased in the EXP simulations and then compared to the control simulation in order to isolate the simulated CAFO emissions from background $\mathrm{SO}_{2}$. As noted previously, the length of the simulation is common in air pollution research (e. g., Loughner et al., 2011; Wang et al., 2011).

Lower-level $\mathrm{SO}_{2}$ concentrations in the control simulation decreased to below 20 pptv with precipitation occurrence and increased to over 40 pptv during the drier periods following rainfall. This was likely due to the reaction of $\mathrm{SO}_{2}$ with water and oxygen to form sulfuric acid $\left(\mathrm{H}_{2} \mathrm{SO}_{4}\right)$ during rainy periods (Menz \& Seip, 2004). Overall, background $\mathrm{SO}_{2}$ concentrations tended to be greater at higher levels than those closer to the surface, and one contributing factor is the presence of liquid precipitation reacting with $\mathrm{SO}_{2}$ in the lower levels. Concentrations of $\mathrm{SO}_{2}$ in the upper levels over dry areas reached up to $100 \mathrm{pptv}$, while those over precipitation ranged between 0 and 30 pptv.

When emissions were increased from the control simulation in successive experimental simulations, increased $\mathrm{SO}_{2}$ concentrations spread much farther from the CAFO emissions locations before and after precipitation. In most cases, however, the higher increases in $\mathrm{SO}_{2}$ stayed limited to an area within a few kilometers of the emission sources. Exceptions to this occurred when lower-level wind speeds in the vicinity were greater, causing these high concentrations to travel farther from their sources before being influenced by other factors. Beyond the emission source locations, any increases in $\mathrm{SO}_{2}$ concentrations above CTRL were mostly under 300 
pptv. Wind direction was the main controlling factor in determining the areas of increased concentrations at any given time, especially during drier conditions, which allowed $\mathrm{SO}_{2}$ to persist for longer periods.

This research can be improved and expanded in several ways. For instance, the simulation period used in this study extended over seven days. However, many of the major changes in $\mathrm{SO}_{2}$ concentrations observed between dry and wet periods occurred within the first four days. With this in mind, future simulations of this kind can have a shorter duration and, therefore, save considerable computational resources. CAFOs primarily emit reduced sulfur compounds that convert to $\mathrm{SO}_{2}$ in the atmosphere. Hydrogen sulfide $\left(\mathrm{H}_{2} \mathrm{~S}\right)$ is the most common of these and can yield $\mathrm{SO}_{2}$ through atmospheric photochemical oxidation. Additional simulations using $\mathrm{H}_{2} \mathrm{~S}$ during the same period can be compared to the preceding $\mathrm{SO}_{2}$ simulations in order to find a secondary relationship beyond that with precipitation occurrence. Future activities may also include observations of $\mathrm{H}_{2} \mathrm{~S}$ and use these data for the modeling research and verification.

Moreover, the methods used in this research can be applied to other locations and under different meteorological conditions. These emission simulations contribute to the research completed in other studies that have focused on CAFO emissions (Loughrin et al., 2011; Quintanar et al., 2013), which showed that the impacts of CAFOs on air quality and warrant attention due to the population that live near these operations.

\section{Acknowledgments}

The authors would like to thank two anonymous reviewers and the Associate Editor (Dr. Steven Quiring) for their valuable comments and suggestions which helped to improve this paper. Authors gratefully acknowledge feedback provided by Dr. Udaysankar Nair for an earlier version of this paper. The mention of any specific product names in this paper does not imply endorsement by the USDA.

\section{Disclosure statement}

No potential conflict of interest was reported by the authors.

\section{Funding}

Jesse Winchester, Rezaul Mahmood, and William Rodgers received funding from the USDA-ARS [Grant \# 58-6445-6-068] to conduct this research. Rezaul Mahmood also acknowledges support from an NSF-ATM Chemistry Grant \#1460418.

\section{ORCID}

William Rodgers (D) http://orcid.org/0000-0001-5291-9471 


\section{References}

Ackermann, I. J., Hass, H., Memmesheimer, M., Ebel, A., Binkowski, F. S., \& Shankar, U. (1998). Modal aerosol dynamics model for Europe: Development and first applications. Atmospheric Environment, 32(17), 2981-2999. https://doi.org/10.1016/S1352-2310(98)00006-5

AHPS (Advanced Hydrologic Prediction Service). (2012). CONUS + Puerto Rico: Current 1-day observed precipitation, data from July 7 to 13, 2012, 1200 UTC. NOAA. http://water.weather. gov/precip/save.php?

Battye, W., Aneja, V., \& Roelle, P. (2003). Evaluation and improvement of ammonia emissions inventories. Atmospheric Environment, 37(27), 3873-3883. https://doi.org/10.1016/S1352-2310 (03)00343-1

Bela, M. M., Barth, M. C., Toon, O. B., Fried, A., Homeyer, C. R., Morrison, H., Cummings, K. A., Li, Y., Pickering, K. E., Allen, D. J., Yang, Q., Wennberg, P. O., Crounse, J. D., St. Clair, J. M., Teng, A. P., O’Sullivan, D., Huey, L. G., Chen, D., Liu, X., Blake, D. R., ... Diskin, G. (2016). Wet scavenging of soluble gases in DC3 deep convective storms using WRF-Chem simulations and aircraft observations wet scavenging of soluble gases in DC3 deep convective storms using WRF-Chem simulations and aircraft observations. Journal of Geophysical Research Atmosphere, 121, 4233-4257. https://doi.org/10.1002/2015JD024623

Bernstein, D., Neelin, J., Li, Q., \& Chen, D. (2012). Could aerosol emissions be used for regional heat wave mitigation? Atmospheric Chemistry and Physics Discussions, 12(9), 23793-23828. https://doi.org/10.5194/acpd-12-23793-2012

Binkowski, F. S., \& Shankar, U. (1995). The regional particulate matter model, 1. Mode description and preliminary results. Journal of Geophysical Research, 100(D12), 26191-26209. https://doi. org/10.1029/95JD02093

Borlée, F., Yzermans, C. J., Aalders, B., Rooijackers, J., Krop, E., Maassen, C. B. M., Schellevis, F., Brunekreef, B., Heederik, D., \& Smit, L. A. M. (2017). Air pollution from livestock farms is associated with airway obstruction in neighboring residents. American Journal of Respiratory and Critical Care Medicine, 196(9), 1152-1161. https://doi.org/10.1164/rccm.201701-00210C

Bunton, B., O'Shaughnessy, P., Fitzsimmons, S., Gering, J., Hoff, S., Lyngbye, M., Thome, P., Wasson, J., \& Werner, M. (2007). Monitoring and modeling of emissions from concentrated animal feeding operations: Overview of methods. Environmental Health Perspective, 115(2), 303-307. https://doi.org/10.1289/ehp.8838

Burkholder, J., Koplin, D., Koplin, D., Koplin, D., Thome, P., \& Wichman, M. (2007). Impacts of waste from concentrated animal feeding operations on water quality. Environmental Health Perspective, 115(2), 308-312. https://doi.org/10.1289/ehp.8839

Chapman, E., Gustafson, W., Jr., Easter, R., Barnard, J., Ghan, S., Pekour, M., \& Fast, J. (2009). Coupling aerosol-cloud-radiative processes in the WRF-Chem model: Investigating the radiative impact of elevated point sources. Atmospheric Chemistry and Physics, 9(3), 945-964. https:// doi.org/10.5194/acp-9-945-2009

Chen, D., Liu, Z., Ban, J., \& Chen, M. (2019). The ${ }_{2} 015$ and ${ }_{2} 016$ wintertime air pollution in China: $\mathrm{SO}_{2}$ emission changes derived from a WRF-Chem/EnKF coupled data assimilation system. Atmospheric Chemistry and Physics, 19(13), 8619-8650. https://doi.org/10.5194/acp-19-8619-2019

Chen, F., \& Dudhia, J. (2001). Coupling an advanced land surface-hydrology model with the Penn State-NCAR MM5 modeling system. Part I: Model implementation and sensitivity. Monthly Weather Review, 129(4), 569-585. https://doi.org/10.1175/1520-0493(2001)129<0569: CAALSH>2.0.CO;2

Chuang, M.-T., Zhang, Y., \& Kang, D. (2011). Application of WRF/Chem-MADRID for real-time air quality forecasting over the Southeastern United States. Atmospheric Environment, 45(34), 6241-6250. https://doi.org/10.1016/j.atmosenv.2011.06.071

Cicerone, R., \& Oremland, R. (1988). Biogeochemical aspects of atmospheric methane. Global Biogeochemical Cycles, 2, 299-332. https://doi.org/10.1029/GB002i004p00299

Egan, S. D., Stauffer, M., Webley, P., Cahill, C. F., \& Dean, J. (2014). WRF-Chem modeling of sulfur dioxide emissions from the 2008 Kasatochi Volcano. Annals of Geophysics, Fast Track, 2. 1-6. https://doi.org/10.4401/ag-6626 
EPA (Environmental Protection Agency). (2014). Animal feeding operations. EPA. http://www. epa.gov/agriculture/anafoidx.html

Feilberg, A., Hansen, M. J., Liu, D., \& Nyord, T. (2017). Contribution of livestock $\mathrm{H}_{2} \mathrm{~S}$ to total sulfur emissions in a region with intensive animal production. Nature Communications, $8(1)$, 1069. https://doi.org/10.1038/s41467-017-01016-2

Freitas, S. R., Longo, K. M., Alonso, M. F., Pirre, M., Marecal, V., Grell, G., Stockler, R., Mello, R. F., \& Gácita, M. S. (2011). PREP-CHEM-SRC - 1.0: A preprocessor of trace gas and aerosol emission fields for regional and global atmospheric chemistry models. Geoscientific Model Development, 4(2), 419-433. https://doi.org/10.5194/gmd-4-419-2011

Gleason, J. F., Sinha, A., \& Howard, C. J. (1987). Kinetics of the gas-phase reaction of $\mathrm{HOSO}_{2}+\mathrm{O}_{2}$ $->\mathrm{HO}_{2}+\mathrm{SO}_{3}$. Journal of Physical Chemistry, 91(3), 719-724. https://doi.org/10.1021/ j100287a045

Grell, G., Dudhia, J., \& Stauffer, D. (1994). A description of the fifth-generation Penn State/NCAR mesoscale model (MM5) (NCAR Technical Note). Boulder, CO: NCAR. http://nldr.library.ucar. edu/repository/assets/technotes/TECH-NOTE-000-000-000-214.pdf

Gross, A., \& Stockwell, W. R. (2003). Comparison of the EMEP, RADM2 and RACM mechanisms. Journal of Atmospheric Chemistry, 44(2), 151-170. https://doi.org/10.1023/A:1022483412112

Guenther, A., Karl, T., Harley, P., Wiedinmyer, C., Palmer, P., \& Geron, C. (2006). Estimates of global terrestrial isoprene emissions using MEGAN (Model of emissions of gases and aerosols from nature). Atmospheric Chemistry and Physics, 6(11), 3181-3210. https://doi.org/10.5194/ acp-6-3181-2006

Hong, S.-Y., \& Lim, J.-O. (2006). The WRF single-moment 6-class microphysics scheme (WSM6). Journal of Korean Meteorological Society, 42(2), 129-151.

Hong, S.-Y., Noh, Y., \& Dudhia, J. (2006). A new vertical diffusion package with an explicit treatment of entrainment processes. Monthly Weather Review, 134(9), 2318-2341. https://doi. org/10.1175/MWR3199.1

Jiang, F., \& Zhao, H. (2008). Numerical modeling of a continuous photochemical pollution episode in Hong Kong using WRF-chem. Atmospheric Environment, 42(38), 8717-8727. https://doi.org/10.1016/j.atmosenv.2008.08.034

Jiang, X., Yang, Z., Liao, H., \& Wiedinmyer, C. (2010). Sensitivity of biogenic secondary organic aerosols to future climate change at regional scales: An online coupled simulation. Atmospheric Environment, 44(38), 4891-4907. https://doi.org/10.1016/j.atmosenv.2010.08.032

Kain, J., \& Fritsch, J. (1993). Convective parameterization for mesoscale models: The Kain-Fritsch scheme. In K.A. Emanuel and D.J. Raymond (eds.) The representation of cumulus convection in numerical models (pp. 165-170). Boston, MA: American Meteorological Society.

Karl, T., Apel, E., Hodzic, A., Riemer, D., Blake, D., \& Wiedinmyer, C. (2009). Emissions of volatile organic compounds inferred from airborne flux measurements over a megacity. Atmospheric Chemistry and Physics, 9(1), 271-285. https://doi.org/10.5194/acp-9-271-2009

Khan, R. R., \& Siddiqui, M. J. A. (2014). Review on effects of particulates; sulfur dioxide and nitrogen dioxide on human health. International Research Journal of Environment Sciences, 3(4), 70-73.

Khaniabadia, Y. O., Polosa, R., Chuturkova, R. Z., Daryanoosh, M., Goudarzie, G., Borgini, A., Tittarelli, A., Basiri, H., Armin, H., Nourmoradi, H., Babaei, A. A., \& Naserian, P. (2017). Human health risk assessment due to ambient $\mathrm{PM} 10$ and $\mathrm{SO}_{2}$ by an air quality modeling technique. Process Safety and Environmental Protection, 111, 346-354. https://doi.org/10.1016/j. psep.2017.07.018

Kim, Y., Sartelet, K., \& Seigneur, C. (2011). Formation of secondary aerosols over Europe: Comparison of two gas-phase chemical mechanisms. Atmospheric Chemistry and Physics, 11 (2), 583-598. https://doi.org/10.5194/acp-11-583-2011

Kleinman, L., Daum, P., Imre, D., Lee, Y., Nunnermacker, L., \& Springston, S. (2002). Ozone production rate and hydrocarbon reactivity in 5 urban areas: A cause of high ozone concentration in Houston. Geophysical Research Letters, 29(10), 1467-1470. https://doi.org/10.1029/ 2001GL014569 
Lee, S., Kim, S., Trainer, M., Frost, G., McKeen, S., Cooper, O., Flocke, F., Holloway, J., Neuman, J., Ryerson, T., Senff, C., Swanson, A., \& Thompson, A. (2011). Modeling ozone plumes observed downwind of New York City over the North Atlantic Ocean during the ICARTT field campaign. Atmospheric Chemistry and Physics, 11, 7375-7397. https://doi.org/10.5194/acp-11-7375-2011

Lin, M., Holloway, T., Carmichael, G., \& Fiore, A. (2010). Quantifying pollution inflow and outflow over East Asia in spring with regional and global models. Atmospheric Chemistry and Physics, 10, 4221-4239. https://doi.org/10.5194/acp-10-4221-2010

Liu, M., Huang, X., Song, Y., Xu, T., Wang, S., Wu, Z., Hu, M., Zhang, L., Zhang, Q., Pan, Y., Liu, X., \& Zhu, T. (2018). Rapid $\mathrm{SO}_{2}$ emission reductions significantly increase tropospheric ammonia concentrations over the North China plain. Atmospheric Chemistry and Physics, 18 (24), 17933-17943. https://doi.org/10.5194/acp-18-17933-2018

Loughner, C., Allen, D., Pickering, K., Zhang, D., Shou, Y., \& Dickerson, R. (2011). Impact of fair-weather cumulus clouds and the Chesapeake Bay breeze on pollutant transport and transformation. Atmospheric Environment, 45(24), 4060-4072. https://doi.org/10.1016/j.atmo senv.2011.04.003

Loughrin, J., Quintanar, A., Lovanh, N., \& Mahmood, R. (2011). Heat flux measurements and modeling of malodorous compounds above an anaerobic swine lagoon. Water, Air, and Soil Pollution, 217(1-4), 463-471. https://doi.org/10.1007/s11270-010-0601-z

Margitan, J. J. (1984). The mechanism of the atmospheric oxidation of sulfur dioxide, catalysis by OH. Journal of Physical Chemistry, 8(15), 3314-3318. https://doi.org/10.1021/j150659a035

Meagher, J. F., Olszyna, K. J., \& Luria, M. (1984). The effect of $\mathrm{SO}_{2}$ gas phase oxidation on hydroxyl smog chemistry. Atmospheric Environment, 18(10), 2095-2104. https://doi.org/10.1016/00046981(84)90195-1

Menz, F., \& Seip, H. (2004). Acid rain in Europe and the United States: An update. Environmental Science and Policy, 7(4), 253-265. https://doi.org/10.1016/j.envsci.2004.05.005

Mesinger, F., DiMego, G., Kalnay, E., Mitchell, K., Shafran, P., Ebisuzaki, W., Jovic, D., Woollen, J., Rogers, E., Berbery, E., Ek, M., Fan, Y., Grumbine, R., Higgins, W., Li, H., Lin, Y., Manikin, G., Parrish, D., \& Shi, W. (2006). North American regional reanalysis. Bulletin of the American Meteorological Society, 87(3), 343-360. https://doi.org/10.1175/BAMS-87-3-343

Mlawer, E., Steven, J., Taubman, J., Brown, P., Iacono, M., \& Clough, S. (1997). Radiative transfer for inhomogenous atmospheres: RRTM, a validated correlated-k model for the longwave. Journal of Geophysical Research, 102(D-14), 16666-16682. https://doi.org/10. 1029/97JD00237

Mnatzaganian, C. L., Pellegrin, K. L., Miyamura, J., Valencia, D., \& Pang, L. (2015). Association between sugar cane burning and acute respiratory illness on the island of Maui. Environment and Health, 14(1), 81. https://doi.org/10.1186/s12940-015-0067-y.

Mosier, A., Kroeze, C., Nevison, C., Oenema, O., Seitzinger, S., \& van Cleemput, O. (1998). Closing the global $\mathrm{N}_{2} \mathrm{O}$ budget: Nitrous oxide emissions through the agricultural nitrogen cycle. Nutrient Cycling in Agroecosystems, 52(2/3), 225-248. https://doi.org/10.1023/ A: 1009740530221

National Research Council. (2003). Air emissions from animal feeding operations: Current knowledge, future needs. The National Academies Press.

NCAR (National Center for Atmospheric Research). (2013). WRF model various downloads. NCAR. http://www.mmm.ucar.edu/wrf/users/downloads.html

Ni, J.-Q., Robarge, W. P., Xiao, C., \& Heber, A. J. (2012). Volatile organic compounds at swine facilities: A critical review. Chemosphere, 89(7), 769-788. https://doi.org/10.1016/j.chemo sphere.2012.04.061

Niemeier, U., Richter, J. H., \& Tilmes, S. (2020). Differing responses of the quasi-biennial oscillation to artificial $\mathrm{SO}_{2}$ injections in two global models. Atmospheric Chemistry and Physics, 20(14), 8975-8987. https://doi.org/10.5194/acp-20-8975-2020

Ntelekos, A., Smith, J., Donner, L., Fast, J., Gustafson, W., Jr., Chapman, E., \& Krajewski, W. (2009). The effects of aerosols on intense convective precipitation in the northeastern United States. Quarterly Journal of the Royal Meteorological Society, 135(643), 1367-1391. https://doi. org/10.1002/qj.476 
Perraud, V., Hone, J. R., Martinez, A. S., Kalinowski, J., Meinardi, S., Dawson, M. L., Wingen, L. M., Dabdub, D., Blake, D. R., Gerber, R. B., \& Finlayson-Pitts, B. J. (2015). The future of airborne sulfur-containing particles in the absence of fossil fuel sulfur dioxide emissions. Proceedings of the National Academy of Sciences, 112(44), 13514-13519. https://doi. org/10.1073/pnas.1510743112

Pope, C., III, Dockery, D., Spengler, J., \& Raizenne, M. (1991). Respiratory health and $\mathrm{PM}_{10}$ pollution: A daily time series analysis. American Review of Respiratory Disease, 144(3_pt_1), 668-674. https://doi.org/10.1164/ajrccm/144.3_Pt_1.668

Pope, C. A., III, \& Dockery, D. W. (2006). Health effects of fine particulate air pollution: Lines that connect. Journal of the Air \& Waste Management Association, 56(6), 709-742. https://doi.org/ 10.1080/10473289.2006.10464485.

Quintanar, A., Mahmood, R., Lovanh, N., Rawley, J., Becerra-Acosta, E., \& Loughrin, L. (2013). Estimating greenhouse gas emissions from a waste lagoon. Applied Engineering in Agriculture, 29(4), 511-519. http://dx.doi.org/10.13031/aea.29.10013

Rumsey, I., \& Aneja, V. (2009, October 19-21). Measurement and modeling of emissions of reduced sulfur compounds from concentrated animal feeding operations. Paper presented at the 8th Annual CMAS Conference. Chapel Hill, NC.

Saide, P., Carmichael, G., Spak, S., Gallardo, L., Osses, A., Mena-Carrasco, M., \& Pagowski, M. (2011). Forecasting urban $\mathrm{PM}_{10}$ and $\mathrm{PM}_{2.5}$ pollution episodes in very stable nocturnal conditions and complex terrain using WRF-Chem CO tracer model. Atmospheric Environment, 45 (16), 2769-2780. https://doi.org/10.1016/j.atmosenv.2011.02.001

Schell, B., Ackermann, I. J., Hass, H., Binkowski, F. S., \& Ebel, A. (2001). Modeling the formation of secondary organic aerosol within a comprehensive air quality model system. Journal of Geophysical Research: Atmospheres, 106(D22), 28275-28293. https://doi.org/10.1029/ 2001JD000384

Sigurdarson, S., \& Kline, J. (2006). School proximity to concentrated animal feeding operations and prevalence of asthma in students. Chest, 129(6), 1486-1491. https://doi.org/10.1378/chest. 129.6.1486

Stockwell, W. R., Middleton, P., Chang, J., \& Tang, X. (1990). The second generation regional acid deposition model chemical mechanism for regional air quality modeling. Journal of Geophysical Research, 16(343-16), 367. https://doi.org/10.1029/JD095iD10p16343

Thornton, D. C., Bandy, A. R., \& Blomquist, B. W. (1997). Transport of sulfur dioxide from the Asian Pacific rim to the North Pacific troposphere. Journal of Geophysical Research, 102(28), 489-28,499. https://doi.org/10.1029/97JD01818

Thornton, D. C., Bandy, A. R., Blomquist, B. W., Davis, D. D., \& Talbot, R. W. (1996). Sulfur dioxide as a source of condensation nuclei in the upper troposphere of the Pacific Ocean. Journal of Geophysical Research, 101(D1), 1883-1890. https://doi.org/10.1029/95JD02273

Thornton, D. C., Bandy, A. R., Tu, F. H., Blomquist, B. W., Mitchell, G. M., Nadler, W., \& Lenschow, D. H. (2002). Fast airborne sulfur dioxide measurements by atmospheric pressure ionization mass spectrometry (APIMS). Journal of Geophysical Research, 107(D22) 4632. https://doi.org/10.1029/2002JD002289

Tie, X., Madronich, S., Li, G., Ying, Z., Zhang, R., Garcia, A., Lee-Taylor, J., \& Liu, Y. (2007). Characterizations of chemical oxidants in Mexico City: A regional chemical dynamical model (WRF-Chem) study. Atmospheric Environment, 41(9), 1989-2008. https://doi.org/10.1016/j. atmosenv.2006.10.053

Tu, F. H., Thornton, D. C., Bandy, A. R., Carmichael, G. R., Tang, Y., Thornhill, K. L., Sachse, G. W., \& Blake, D. R. (2004). Long-range transport of sulfur dioxide in the central pacific. Journal of Geophysical Research, 109(D15), D15S08. https://doi.org/doi:10.1029/ 2003JD004309.

Ukhov, A., Mostamandi, S., Krotkov, N., Flemming, J., da Silva, A., Li, C., Fioletov, V., McLinden, C., Anisimov, A., Alshehri, Y. M., \& Stenchikov, G. (2020). Study of SO2 pollution in the Middle East using MERRA-2, CAMS data assimilation products, and high-resolution WRF-Chem simulations. Journal of Geophysical Research: Atmospheres, 125, e2019JD031993. https://doi. org/10.1029/2019JD031993 
USDA (United States Department of Agriculture). (2013). Animal feeding operations (AFO) and concentrated animal feeding operations (CAFO). USDA. http://www.nrcs.usda.gov/wps/portal/ $\mathrm{nrcs} / \mathrm{main} / \mathrm{national} / \mathrm{plantsanimals/livestock/afo/}$

Wang, M., Zhu, T., Zhang, J. P., Zhang, Q. H., Lin, W. W., Li, Y., \& Wang, Z. F. (2011). Using a mobile laboratory to characterize the distribution and transport of sulfur dioxide in and around Beijing. Atmospheric Chemistry and Physics, 11(22), 11631-11645. https://doi.org/10. 5194/acp-11-11631-2011

Wang, X., Liang, X., Jiang, W., Tao, Z., Wang, J., Liu, H., Han, Z., Liu, S., Zhang, Y., Grell, G., \& Peckham, S. (2010). WRF-Chem simulation of East Asian air quality: Sensitivity to temporal and vertical emissions distributions. Atmospheric Environment, 44(5), 660-669. https://doi.org/ 10.1016/j.atmosenv.2009.11.011

Wilczak, J., McKeen, S., Djalalova, I., Grell, G., Peckham, S., Gong, W., Bouchet, V., Moffet, R., McHenry, J., McQueen, J., Lee, P., Tang, Y., \& Carmichael, G. (2006). Bias-corrected ensemble and probabilistic forecasts of surface ozone over eastern North America during the summer of 2004. Journal of Geophysical Research, 111(D-23), 2156-2202. https://doi.org/10.1029/ 2006JD007598

Winchester, J. (2015). Emissions from concentrated animal feeding operations during wet and dry periods in the Southeastern United States [Master's Thesis]. Western Kentucky University.

Winkel, A., Mosquera, J., Groot Koerkamp, P. W. G., Ogink, N. W. M., \& Aarnink, A. J. A. (2015). Emissions of particulate matter from animal houses in the Netherlands. Atmospheric Environment, 111, 202-212. https://doi.org/10.1016/j.atmosenv.2015.03.047

Wu, Z., Wang, X., Chen, F., Turnipseed, A., Guenther, A., Niyogi, D., Charusombat, U., Xia, B., Munger, J., \& Alapaty, K. (2011). Evaluating the calculated dry deposition velocities of reactive nitrogen oxides and ozone from two community models over a temperate deciduous forest. Atmospheric Environment, 45(16), 2663-2674. https://doi.org/10.1016/j.atmosenv.2011.02.063

Yerramilli, A., Srinivas, C., Dasari, H., Tuluri, F., White, L., Baham, J., Young, J., Hughes, R., Patrick, C., Hardy, M., \& Swanier, S. (2009). Simulation of atmospheric dispersion of elevated releases from point sources in Mississippi Gulf Coast with different meteorological data. International Journal of Environmental Research and Public Health, 6(3), 1055-1074. https:// doi.org/10.3390/ijerph6031055

Zhang, Y., Wen, X., \& Jang, C. (2010). Simulating chemistry-aerosol-cloud-radiation- climate feedbacks over the continental U.S. using the online-coupled weather research forecasting model with chemistry (WRF/Chem). Atmospheric Environment, 44(29), 3568-3582. https:// doi.org/10.1016/j.atmosenv.2010.05.056

Zhang, Y., Zhu, Z., Zheng, Y., Chen, Y., Yin, F., Zhang, W., Dong, H., \& Xin, H. (2019). Characterization of volatile organic compound (VOC) emissions from swine manure biogas digestate storage. Atmosphere, 10(7), 411. https://doi.org/doi:10.3390/atmos10070411.

Zhong, M., Saikawa, E., Liu, Y., Naik, V., Horowitz, L. W., Takigawa, M., Zhao, Y., Neng-Huei, L., \& Stone, E. A. (2016). Air quality modeling with WRF-Chem v3.5 in East Asia: Sensitivity to emissions and evaluation of simulated air quality. Geoscientific Model Development, 9(3), 1201-1218. https://doi.org/10.5194/gmd-9-1201-2016 